\title{
A NEW FAMILY OF TRIASSIC LOBSTERS (DECAPODA: ASTACIDEA) FROM BRITISH COLUMBIA AND ITS PHYLOGENETIC CONTEXT
}

\author{
LISA AMATI, ${ }^{1}$ RODNEY M. FELDMANN, ${ }^{2}$ AND JOHN-PAUL ZONNEVELD ${ }^{3}$ \\ ${ }^{1}$ School of Geology and Geophysics, University of Oklahoma, Norman 73019, <lamati@ou.edu>, \\ ${ }^{2}$ Department of Geology, Kent State University, Kent, Ohio 44242, < rfeldman@kent.edu>, and \\ ${ }^{3}$ Geological Survey of Canada, 3303-33rd Street N.W., Calgary, Alberta T2L 2A7, Canada, <jzonneve@nrcan.ga.ca>
}

\begin{abstract}
Chimaerastacus pacifluvialis, new genus and species, is established on the basis of fossils from the Middle Triassic Liard Formation of northeastern British Columbia. It has well-defined cervical, postcervical, and branchiocardiac grooves; three longitudinal ridges on the cephalic region; and true chelae on the first through third pereiopods. The morphological features of the carapace are a combination of traits used to define both the erymids and the glypheids. A cladistic analysis of 31 decapod genera defines the Astacidea as a monophyletic group, supports the inclusion of the Glypheoidea within the infraorder Astacidea, illustrates the relationships of the Glypheoidea with other astacid groups, and suggests erection of a new family, the Chimaerastacidae, for our new genus and species of decapod. Specimens of $C$. pacifluvialis are preserved in a sandy bioclastic floatstone that was deposited near the Peace River Embayment in the Middle Triassic. The host lithology suggests that the decapods inhabited a transitional environment between low relief biostromes and the shoreface. This environment provided a unique set of conditions that allowed exceptional preservation of the decapod material.
\end{abstract}

\section{INTRODUCTION}

$\mathrm{L}$ ITTLE IS known about the evolutionary relationships of Early and Middle Triassic decapod crustaceans. Marine rocks of Triassic age are not exposed extensively anywhere in the world, and decapod body fossils are relatively rare. The paucity of Permian and Triassic lobster fossils contributes to uncertainty regarding the ancestor-descendant relationships of living and extinct taxa. Thus, the discovery of new Triassic localities preserving new lobster taxa is extremely important.

Most known Triassic decapod localities are Tethyan or Eurasian. Twenty-six species of Triassic lobsters have been described from 17 sites extending from western Siberia to Italy (cited herein). In contrast, only four North American sites have been described previously (Fig. 1). Therefore, the 1996 discovery of hundreds of well-preserved decapod remains in the Triassic Liard Formation of British Columbia is extraordinary, not only for the extreme abundance of specimens, but also for the new insight these North American decapods provide into the evolution of the group. In this study, we establish the family Chimaerastacidae for Chimaerastacus pacifluvialis new genus and species. A phylogenetic analysis based on characters preservable in the fossil record allows us to evaluate the relationships of taxa in the order Decapoda Latreille, 1802. The study also examines the ecological relationships of taxa preserved in the Liard Formation and addresses the environmental conditions that were present at the time of deposition.

\section{PREVIOUS WORK}

Until the discovery of the British Columbia fauna, only four genera of Triassic lobsters had been described from North America. A single specimen of Litogaster turnbullensis, consisting of a disarticulated cephalothorax, abdomen and partial appendages (Fig. 2), was collected from the Thaynes Formation (Early Triassic) near Hot Springs, Idaho (Schram, 1971). Its assignment to the genus Litogaster, which previously had been known only from Germany, extended the geographic range of the genus to North America.

Another decapod consisting of a single, partial carapace preserved in dorsal view was discovered in Upper Triassic rocks of Nevada. The dorsal portions of the cervical, postcervical, and branchiocardiac grooves can be observed, but the cephalic region and posterior and ventral margins were not recovered. Van Straelen (1936) created a new genus and species, Triasiglyphea mulleri, for this specimen (Fig. 2). A second specimen was later found in the same strata in Nevada, preserved in right lateral view. Förster (1967) noted the similarities this specimen shared with Pseudoglyphea and assigned both specimens to that genus.

A second Upper Triassic lobster, Platypleon nevadensis, was recovered from the same site in Nevada. The fossil consists of the fifth and sixth abdominal segments and a portion of one uropod. Van Straelen (1936) assigned this single, partial specimen to a new genus in the family Coleiidae based on the dorsoventrally compressed nature of the abdomen and the diaresis of the preserved uropod. Glaessner (1969) tentatively reassigned the genus to the family Platychelidae.

In 1988, Miller and Ash described a new species of macruran from the Chinle Formation in Petrified Forest National Park, which they referred to Enoploclytia in the Erymidae. Although the specimen has not been examined, careful study of their illustration of the part and counterpart clearly documents placement within the Astacidea, but shows no evidence that it is an erymid. The specimen bears three chelate pereiopods, with the first much larger than the others. There is a long, serrated rostrum and the abdomen bears pointed terminations on the pleura. Beyond that, the preservation is such that other details of morphology are difficult or impossible to interpret. In particular, the nature of the carapace grooves is obscure. Species of Enoploclytia tend to have strong exoskeletons with coarse nodes or spines. There is no indication that the Chinle material bears any ornamentation on the exoskeleton, other than the rostral spines. Thus, it is unlikely that the material is an erymid. It is more likely an astacid, possibly related to Pacifastacus. Pacifastacus is known from the fossil record in the form of $P$. chenoderma (Cope, 1871) from Miocene and Pliocene (?) occurrences in Idaho and Oregon (Feldmann et al., 1981). The Astacidae are freshwater organisms whereas the Erymidae currently are known only from marine rocks.

Hasiotis and Mitchell (1989) illustrated a single, badly crushed decapod specimen from a burrow in the Chinle Formation near Monticello, Utah. The illustrated specimen was one of many collected in the region; however, because of poor preservation, Hasiotis and Mitchell did not identify the specimens except to note that they bore some resemblance to Cambarus. Although we would concur that further identification is probably not warranted, it is important to note that the specimen illustrated (Hasiotis and Mitchell, 1989, fig. 3A) does exhibit well-developed chelae. Neither of the occurrences from the Chinle Formation have specimens well-enough preserved to be included in the cladistic analysis. 


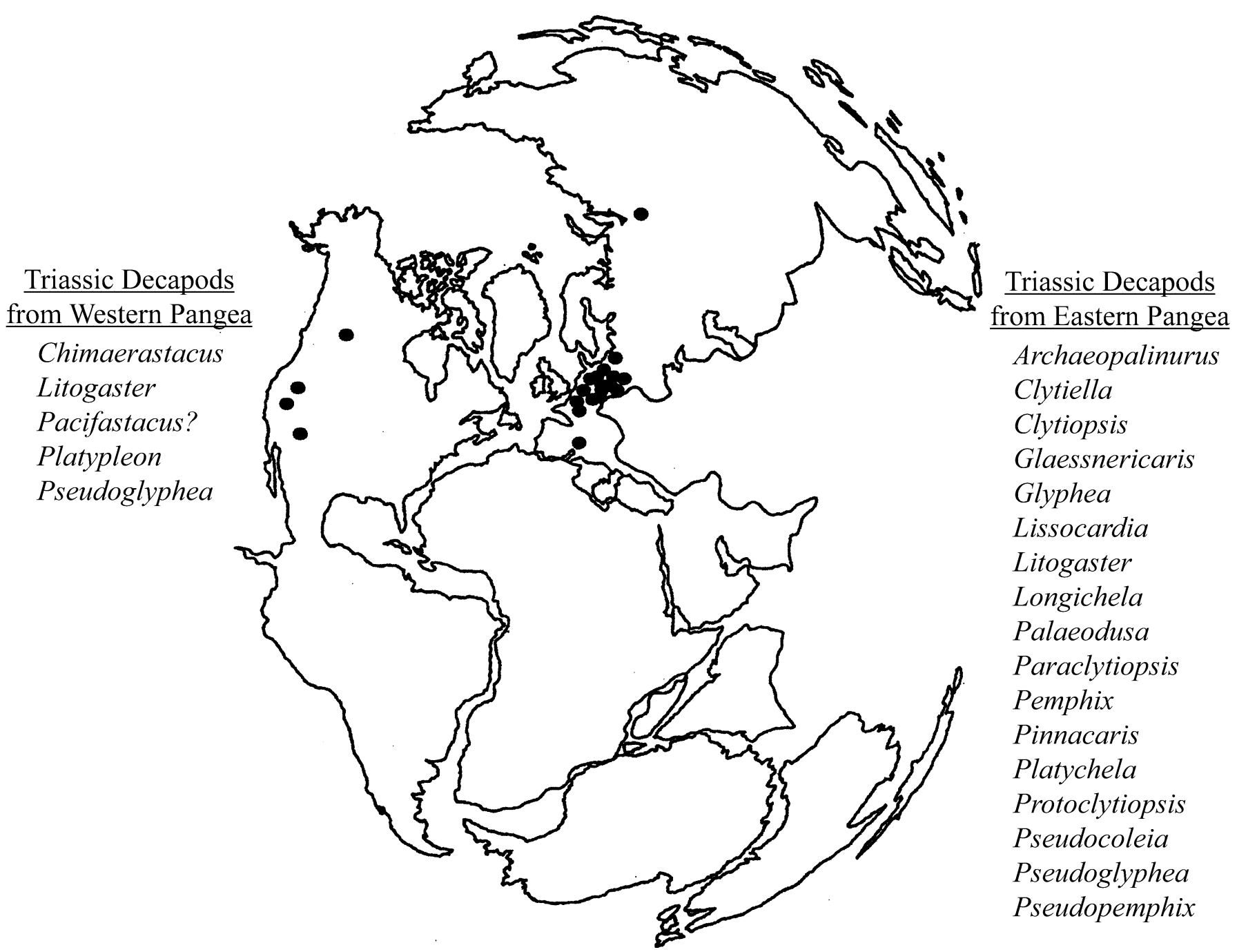

FIgURE 1-Map showing distribution of Triassic lobster localities in Eurasian and Tethyan regions on the eastern margin of Pangea and North American localities on the western margin of Pangea. Genera discovered in each area are listed (Lambert equal-area plot modified from Smith et al., 1981).

\section{GEOLOGIC SETTING}

Specimens of Chimaerastacus pacifluvialis were collected from the upper Liard Formation in northeastern British Columbia along the Peace Reach of Williston Lake (Fig. 3). Seasonal fluctuations in water level scour the shores of the lake providing some of the best exposures of Middle Triassic rocks in the Rocky Mountain outcrop belt. The Liard Formation is a variably thick succession of calcareous sandstone and arenaceous limestone that was deposited within and adjacent to the Peace River embayment in the Middle Triassic (Gibson and Barclay, 1989). The Liard Formation conformably overlies and intertongues with shale, siltstone, and very fine-grained sandstone of the Toad Formation and is overlain by interstratified carbonate, evaporates, and sandstone of the Charlie Lake Formation (Fig. 4). These three units comprise an overall shallowing upward succession that was deposited on the western margin of the North American craton (Zonneveld et al., 1997b; Zonneveld, 1999).

The Liard Formation is characterized by hard gray calcareous to dolomitic sandstone and siltstone, and sandy to silty bioclastic limestone (Gibson, 1975) (Fig. 5). The upper Liard Formation reflects deposition in a mixed siliciclastic-carbonate, barred barrier island shoreface setting (Zonneveld et al., 1997b). Low relief biostromes dominated by terebratulid brachiopods, articulate crinoids and cidaroid echinoids were locally prevalent features of the Liard shoreface and are largely responsible for the high taxonomic diversity that characterizes the Liard Formation (Zonneveld et al., 1997b; Zonneveld, 2001). Specimens of Chimaerastacus are preserved in a sandy bioclastic floatstone with a calcareous mud/silt matrix. These sediments were deposited on the flanks of the brachiopodechinoderm biostromes. Quartz sand becomes more abundant toward the top of the unit. In addition to the decapod crustacean body fossils, large bioclasts consist of discinid, terebratulid, and spiriferid brachiopods; bivalves; gastropods; echinoid and crinoid fragments; isolated skeletal elements and tooth plates of palaeonisciform and actinopterygian fish; reptile (ichthyosaur and thalaltosaur) bones; and eight biostratigraphically important species of ammonoids. Although thin-sections and polished slabs provide evidence of bioturbation, the only trace fossil identified is the horizontal burrow Planolites (Zonneveld, 1998).

The Liard Formation has been identified as Ladinian to lower Carnian in age using conodont biozonation (Orchard and Tozer, 1997). The decapod crustaceans occur in three parasequences 


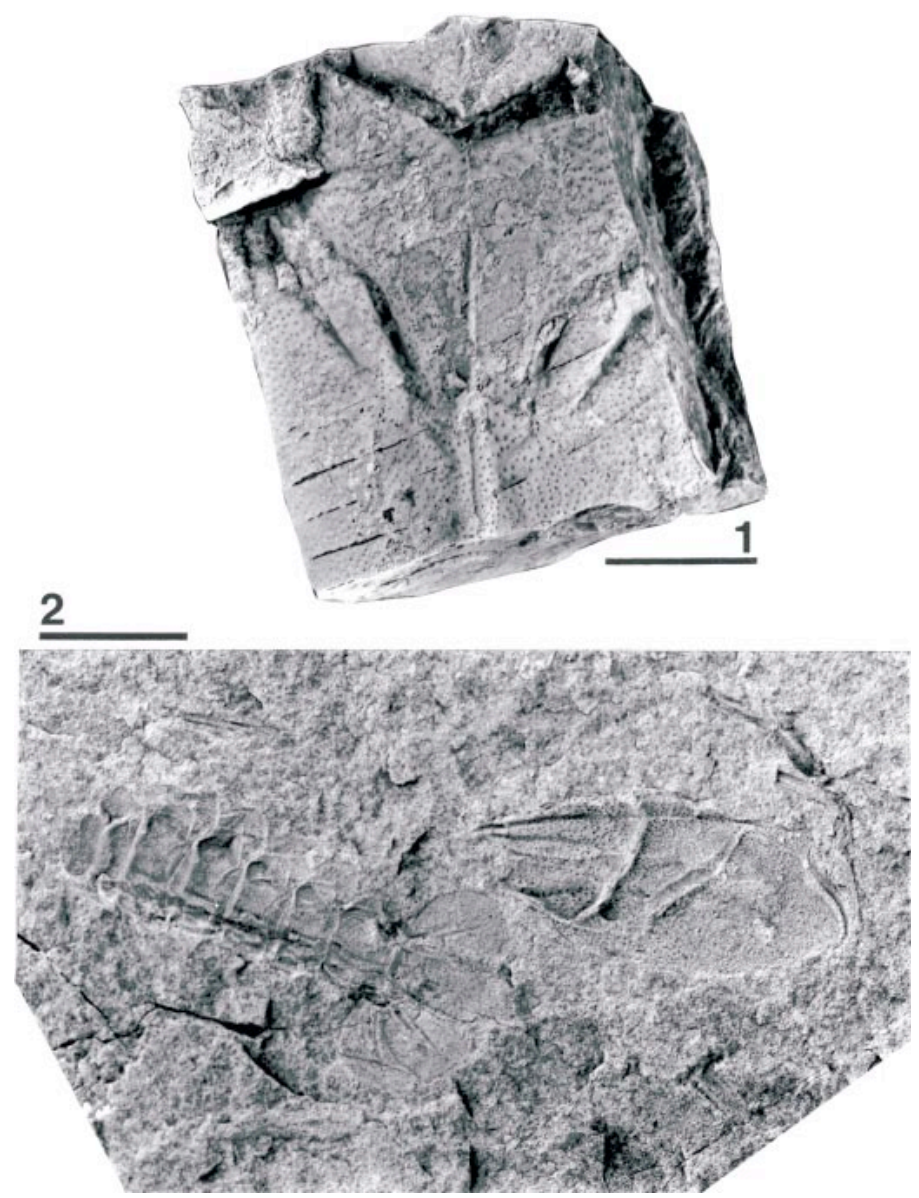

FIGURE 2-1, Pseudoglyphea mulleri (Van Straelen), dorsal portions of cervical, postcervical and branchiocardiac grooves (IRSNB IG 10850) from Pilot Mountains, Nevada, $\times 1.5$. 2, Litogaster turnbullensis (Schram), mold of right lateral portion of cephalothorax and mold of dorsal portion of abdomen (FMNH PE 16215) from near Hot Springs, Idaho, $\times 1.5$. IRSNB = Institut Royal des Sciences Naturelles de Belgique; FMNH $=$ Field Museum of Natural History.

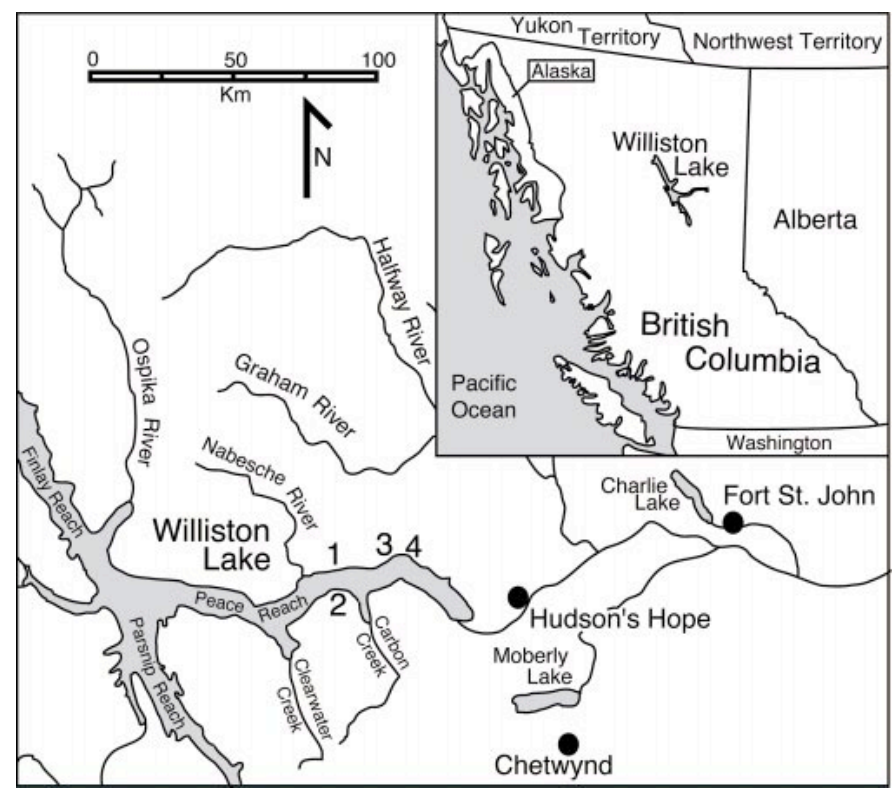

within the highstand systems tract of a single stratigraphic sequence (Zonneveld, 1999). Co-occurrence of the conodonts Paragondolella inclinata and Budurovignathus mungoensis within the decapod-bearing strata indicate deposition within the upper Ladinian Sutherlandi Zone (Mosher, 1973; Orchard and Tozer, 1997; Zonneveld et al., 1997b; Zonneveld, 1999).

\section{MATERIAL AND METHODS}

The specimens of $C$. pacifluvialis used in this study were collected over a four-year period by researchers from The University of Alberta, The University of Calgary, and Kent State University. The orientations of in situ body fossils were measured by noting the direction of true north on the matrix adjoining the specimen and then measuring the angle between north and the long axis of the cephalothorax. The stratigraphic level of each in situ specimen was noted in order to determine the distribution of decapods within the decapod-bearing layer.

The decapod fossils are preserved in remarkable detail as molds

$\leftarrow$

Figure 3-Map of Williston Lake. Localities from which decapod crustaceans were collected are: 1, Brown Hill, 2, Glacier Spur, 3, Aylard Creek. Inset shows location of Williston Lake in northeastern British Columbia (modified from Zonneveld et al., 1997a). 


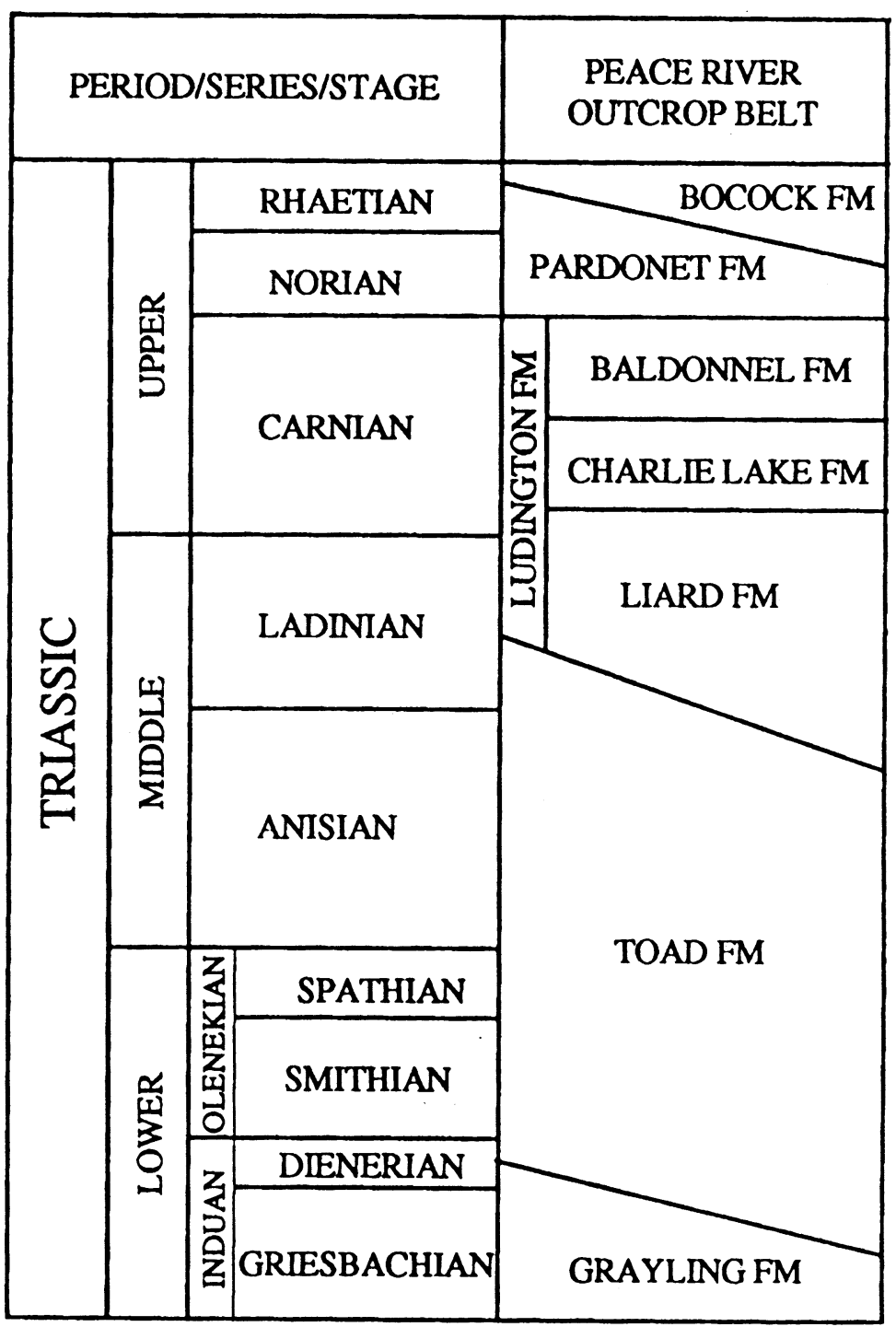

FIGURE 4-Triassic stratigraphic nomenclature of northeastern British Columbia from the area of Williston Lake (modified from Tozer, 1994).

and as body fossils. In addition to some nearly complete specimens, isolated fragments of nearly every preservable body part have been recovered. The nearly complete body fossils were used to make measurements of length and width ratios, but the groove patterns on these specimens were often difficult to distinguish. This is most likely the result of their being preserved in Salter's Position, indicating that the fossil is a molt of the organism. In modern lobsters, the carapace material is partially resorbed prior to molting, making the carapace thin and weak. This may cause the details of carapace ornamentation to be obscured during fossilization.

No preparation was necessary for the examination of the decapod fossils. However, because the lobsters are small in size and were compressed upon preservation, details are difficult to interpret in a hand sample. Specimens were whitened with ammonium chloride for examination and were photographed at two to three times the normal size. Angles of carapace grooves relative to the midline were measured and are listed in Table 1. Measurements were made of lengths and heights of the fossils according to the diagram in Figure 10 (Table 2).

\section{PHYLOGENETIC ANALYSIS}

Overview.-There has been a long and vigorous debate about the placement of family-level taxa in the Astacidea and, for that matter, the very use of the term Astacidea. The analyses of Scholtz and Richter (1995) and Schram (2001) include only recent decapod taxa and question the monophyly of the Astacidea as it is traditionally defined. Their analyses are based in large part on characters of soft-part anatomy, reproductive behavior, sperm morphology and embryological history and result in a phylogenetic scheme necessitating the introduction of several new names for presumed monophyletic taxa throughout the Decapoda.

Another important recent work (Martin and Davis, 2001) presents a classification of the Decapoda that might be viewed as a compromise position, also based on neontological criteria that can not be applied to fossil taxa. Many of the reassignments in the Martin and Davis classification bear a resemblance to those of Scholtz and Richter (1995) and Schram (2001), but traditional names of the taxa have been conserved. Martin and Davis recognize the conventional classification of the Astacidea, with the addition of the Enoplometopoidea and Glypheoidea, and consider 


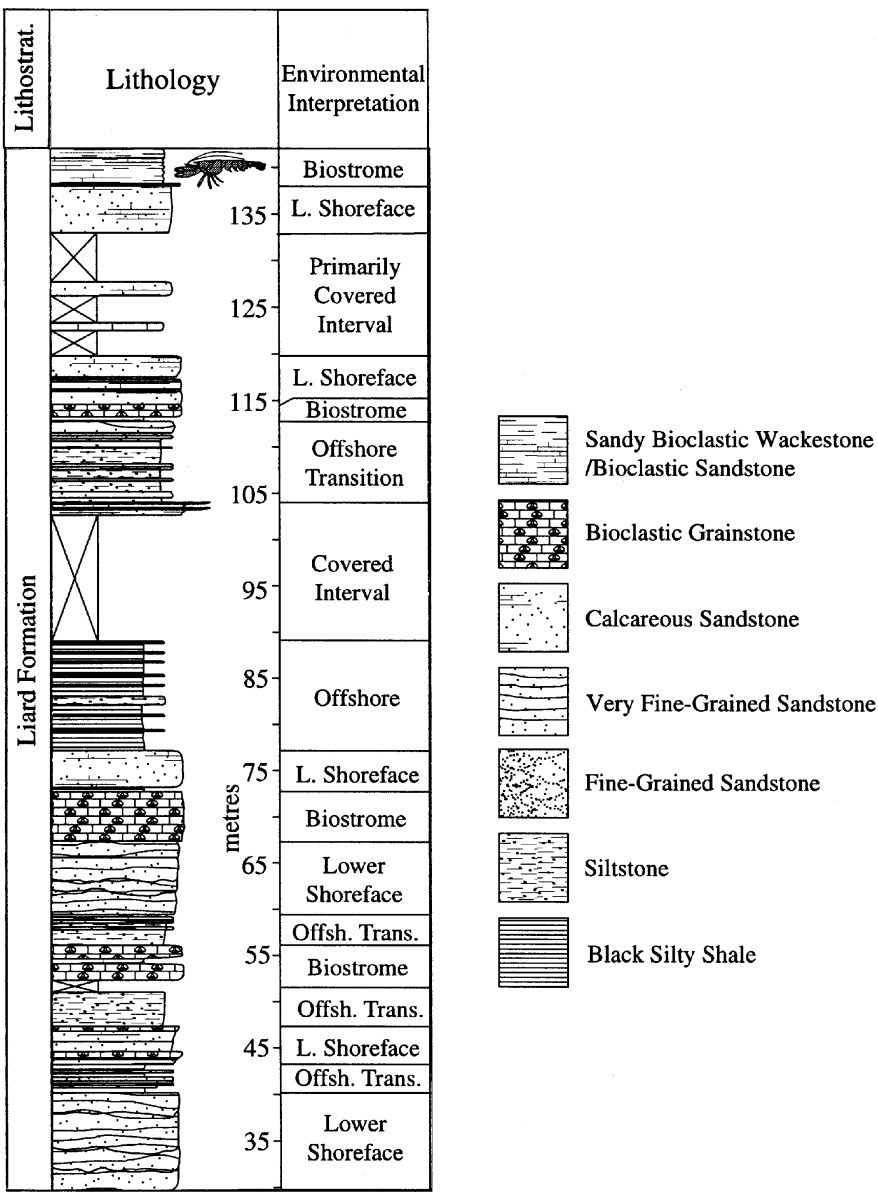

FIGURE 5-Stratigraphic section showing rock types and general depositional environments of the Liard Formation at Aylard Creek (modified from Zonneveld et al., 1997a). The stratigraphic level of the decapod strata is indicated by the decapod pictograph.

the group to be monophyletic. Including the glypheids in the infraorder Astacidea introduces a problem of nomenclature. The Astacidea have traditionally been grouped into families, while the Palinura are arranged in superfamilies. In order to maintain a uniform level of hierarchical classification, we follow the precedent of Martin and Davis (2001) in using the superfamily level of classification for clades within the Astacidea (Nephropoidea, Glypheoidea, Erymoidea). Martin and Davis (2001) further suggest that it is misleading to treat the two groups of crayfish, Astacoidea and Parastacoidea, as superfamilies. We agree and retain the traditional rank of family for the Astacidae and Parastacidae and name the monophyletic superfamily Astacoidea.

A molecular analysis of decapod relationships using nuclear and mitochondrial DNA also supports the monophyly of the Astacidea (Crandall et al., 2000). This analysis produced a monophyletic clade including the Astacoidea, Parastacoidea and $\mathrm{Ne}$ phropoidea.

The present study seeks to answer questions of taxonomic affinity of fossil decapods and, therefore, cannot employ the same characters used in the studies mentioned above. Instead, the phylogeny generated herein is based solely on morphological characters that are preserved in the fossil record. Prior research suggests that including fossil taxa in morphology-based phylogenetic analyses provides insight into phylogenetic relationships not possible when limiting analyses to modern taxa (e.g., Gautier et al.,
1988; Donoghue et al., 1989; O'Leary and Geisler, 1999). Incorporation of fossil taxa into the analysis thus provides an important basis for comparison with the works of Scholtz and Richter (1995), Schram (2001), and Martin and Davis (2001).

Chimaerastacus pacifluvialis is most appropriately classified within the infraorder Astacidea Latreille, 1802, as emended herein. However, it shares distinctive characters with certain members of the superfamily Glypheoidea, including three longitudinal ridges on the cephalic region and the placement of the cervical, postcervical and branchiocardiac grooves. The Glypheoidea has been traditionally placed within the infraorder Palinura, although Forest and de Saint Laurent (1989) suggested that it be removed. The glypheids possess only two characteristics that might argue against their inclusion within the infraorder Astacidea: presence of subchelae and, by current definition, the fusion of the epistome with the frontal margin of the carapace. An examination of numerous, well-preserved fossil glypheid specimens from the collection at Kent State University indicates that, although the epistome has a long edge of contact with the frontal margin of the carapace, it is not physically fused with the carapace (Feldmann and de Saint Laurent, 2002) as in brachyurans and many palinurans. This observation is confirmed by studies of the relatively recently discovered extant member of this group, Neoglyphea inopinata (Forest and de Saint Laurent, 1981, 1989).

Forest and de Saint Laurent (1989) further suggest that the Pemphicidae, and particularly the Mecochiridae, might not belong to the Glypheidae in the superfamily Glypheoidea. These authors placed the Glypheoidea, excluding the Pemphicidae and the Mecochiridae, into a new infraorder, the Glypheidea Forest and de Saint Laurent. This change was based on new information about the glypheids derived from study of Neoglyphea inopinata (Forest and Saint Laurent, 1981, 1989).

We conducted a cladistic analysis of 31 fossil and recent genera from the order Decapoda in order to evaluate the relationship of Chimaerastacus with glypheids, the relationship of glypheids with other members of the Astacidea, and the status of the Astacidea as a monophyletic group.

Explanation of characters and state names.-To perform the cladistic analysis, decapod families were represented by genera rather than species. This allowed the use of broad morphological characters for coding, reduced the number of character states necessary, and lessened the possibility of coding ecophenotypic characters.

This analysis differs from those examining extant taxa in that only morphological features that are preserved readily in fossil taxa were used. Features that have been emphasized in diagnoses of families were used whenever possible. Of the 21 characters chosen, seven deal with groove patterns (Appendix 1) although the biological significance of these grooves is still poorly known. Secretan (1973) and Glaessner (1960) suggested that carapace grooves mark the boundaries between internal segmentation, while Albrecht (1981) and Tshudy and Babcock (1997) have concluded that carapace grooves are the external expression of sites of muscle attachment. We agree with Tshudy and Babcock (1997) that, under either interpretation, carapace grooves represent fundamental features of morphology that should be phylogenetically significant.

All characters were coded using out-group comparison. Most of the characters and character states used in this analysis are selfexplanatory and are listed in Appendix 1. Characters or the methods used in coding that require further explanation are described in detail below. Standard carapace groove designations are indicated in parentheses, and line drawings showing groove patterns of representative species of each astacidean genus are given in Figure 6.

1. Cephalic Ridges. Distinct longitudinal ridges on the cephalic 


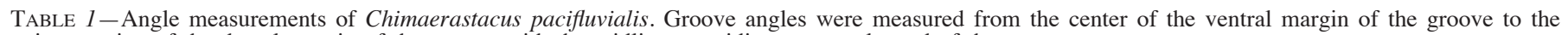
intersection of the dorsal margin of the groove with the midline, providing a general trend of the groove.

\begin{tabular}{|c|c|c|c|c|}
\hline Specimen number & $\begin{array}{c}\text { Intersection } \\
\text { dorsal/ posterior } \\
\text { margin }\end{array}$ & $\begin{array}{l}\text { Trend of cervical } \\
\text { groove }\end{array}$ & $\begin{array}{c}\text { Trend of branchiocardiac } \\
\text { groove }\end{array}$ & $\begin{array}{c}\text { Trend of postcervical } \\
\text { groove }\end{array}$ \\
\hline \multicolumn{5}{|l|}{ Type A } \\
\hline 97.121 .015 & $86^{\circ}$ & $63^{\circ}$ & $51^{\circ}$ & $45^{\circ}$ \\
\hline 97.121 .034 & $78^{\circ}$ & $64^{\circ}$ & $53^{\circ}$ & $45^{\circ}$ \\
\hline 97.121 .572 & $76^{\circ}$ & $70^{\circ}$ & $57^{\circ}$ & $47^{\circ}$ \\
\hline \multicolumn{5}{|l|}{ Type B } \\
\hline 97.121 .543 & $64^{\circ}$ & $83^{\circ}$ & $67^{\circ}$ & $53^{\circ}$ \\
\hline 97.121 .007 & $89^{\circ}$ & $74^{\circ}$ & $61^{\circ}$ & $47^{\circ}$ \\
\hline 97.121 .524 & - & $78^{\circ}$ & $66^{\circ}$ & $55^{\circ}$ \\
\hline
\end{tabular}

region are diagnostic characters of the Glypheoidea. Groups such as the nephropids and erymids can have lateral carinae on the cephalic region, but these are relatively reduced in height and were coded as weak to absent.

2. Urogastric Groove (u). Holthuis (1974) used this term for the posterior fork of a bifurcation at the dorsal end of the postcervical groove (c). This groove has been interpreted as the branchiocardiac groove (a) by some authors (Glaessner, 1969), but does not appear to be homologous. Grooves that arise from the dorsal end of the postcervical groove and are directed toward the midline are coded as urogastric grooves. Those that arise from the postcervical groove but are directed toward the posterior are coded as branchiocardiac grooves. Hoploparia (Feldmann et al., 1977, pl. 3, figs. 1-6 and text fig. 7) is an example in which the branchiocardiac groove is present ventral to the urogastric groove (Fig. 6).

3. Branchiocardiac Groove Origin. Methods for describing and interpreting carapace grooves vary. It is more important that homologous features are coded consistently than what name is given to each groove. For each taxon considered, a line drawing was made and the grooves were coded uniformly (Fig. 6). This process was also used for coding the postcervical groove.

The ventral extension of the branchiocardiac groove (a) has not been identified consistently among taxa. In Eryma (Förster, 1966, fig. 12) for example, this groove appears to extend ventrally to connect with the hepatic groove $\left(b_{1}\right)$. The postcervical groove (c) arises from the branchiocardiac groove (a) above this point. In Nephrops, (Holthuis, 1974, fig. 24, B) the branchiocardiac groove (a) is absent and the postcervical groove (c) extends ventrally to connect with the hepatic groove $\left(\mathrm{b}_{1}\right)$. In other taxa, such as Hoploparia (Feldmann et al., 1977, pl. 3, figs. 1-6 and text fig. 7), some authors imply that the hepatic groove $\left(b_{1}\right)$ extends dorsally to connect with the cervical groove (e).

4. Intercervical Groove $\left(c^{\prime}\right)$. This term is not always used in the literature, especially for extinct taxa. Holthuis (1974) illustrated this groove as an anterior extension of the postcervical groove (c) on the nephropid carapace. In this analysis, the intercervical groove $\left(c^{\prime}\right)$ was coded as present in erymids such as Eryma (Förster, 1966, fig. 12) and Enoploclytia (Förster, 1966, figs. 33-34).

5. Attachment Site of the Adductor Testis Muscle (x). One of the most distinctive features of Chimaerastacus is the definition of the attachment site of the adductor testis muscle by the ventral bifurcation of the branchiocardiac groove (a). The attachment site is also defined in Pseudopemphix, but by the ventral extensions of both the branchiocardiac (a) and postcervical (c) grooves.

Taxa used in cladistic analysis. - The purpose of this analysis is to determine which families belong to the infraorder Astacidea and to elucidate the relationships of these groups. Other taxa used in the analysis were included as "place holders" that allow us to test the monophyletic status of the Astacidea. Information regarding these taxa provides an interesting framework for future studies, but will not be commented on in great detail in the present work. Fossil genera were selected based on the availability of well-preserved and complete specimens. Taxa such as Protoclytiopsis antiqua (Birstein, 1958), Palaeopemphix (Gemmellaro, 1890), Litogaster turnbullensis (Schram, 1971), and Lissocardia (Förster, 1967) would have been interesting additions to the analysis, but the material is too fragmentary for comprehensive coding.

Results.-A parsimony analysis was conducted using PAUP* version 4.0b10 (Swofford, 2000). All characters were unordered and Penaeus and Stenopus were designated as out-groups. A heuristic search of 100 random replicates using TBR branch-swapping and ACCTRAN optimization was used. The 10,573 trees obtained from the heuristic search have a tree length of 70 steps, a consistency index of 0.571 , a rescaled consistency index of 0.446 and a retention index of 0.781 . Following the initial heuristic search, characters were reweighted using the rescaled consistency index and another heuristic search of 100 random replicates was run using TBR branch-swapping and ACCTRAN optimization. The result is five equally parsimonious trees with tree lengths of 40.495 steps, a consistency index of 0.642 , a rescaled consistency index of 0.524 and a retention index of 0.815 . A strict consensus of the five trees is shown in Figure 7. Figure 8 shows an optimized character distribution of one of the five trees using ACCTRAN optimization. This tree was chosen because it is the most resolved of the five and places the Nephropoidea lower in the tree than the Astacoidea, which is in closer agreement with the analyses of Scholtz and Richter (1995) and Schram (2001). An analysis with the same parameters was run using DELTRAN optimization and resulted in a strict consensus tree that is identical to the tree obtained using ACCTRAN optimization. The only significant difference in character distribution using DELTRAN optimization involves the fractosternum. Instead of arising at node 55 and then being lost at node 50 and node 47, the fractosternum is independently derived at node 44 and at node 54 and lost at node 50 .

Discussion--Our analysis suggests that palinuran lobsters are a paraphyletic group. Representatives of the family Palinuridae form a clade based on the absence of chelae on all pereiopods (character 13[2]) and an uncalcified posterior portion of the telson (character 18[3]). The family Scyllaridae is usually considered to be closely related to the Palinuridae, with both families classified in the superfamily Palinuroidea. Our analysis groups Scyllarus with the Polychelidae based on the presence of two apomorphies: a first pereiopod that is larger than the second through fifth pereiopods (character 15[1]) and the presence of a dorsal ridge on the abdomen (character 16[1]). This is an interesting result that warrants further investigation in the future. 
1.

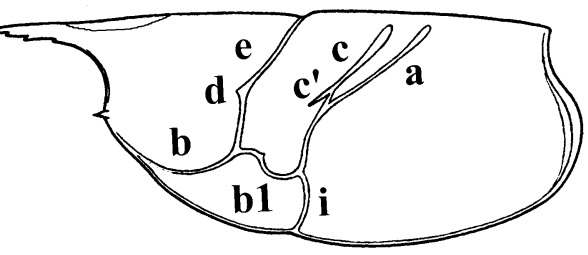

Eryma

3.

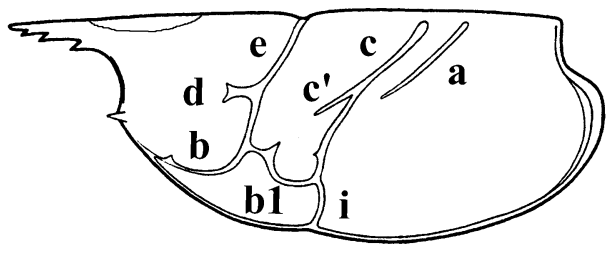

Enoploclytia

5.

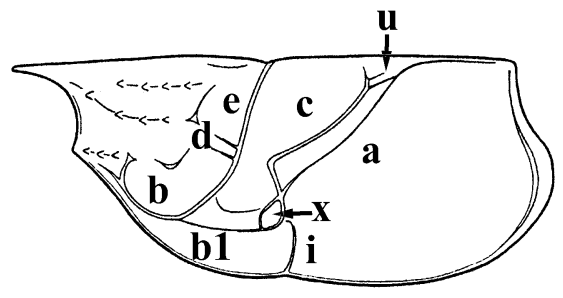

Pseudopemphix

7.

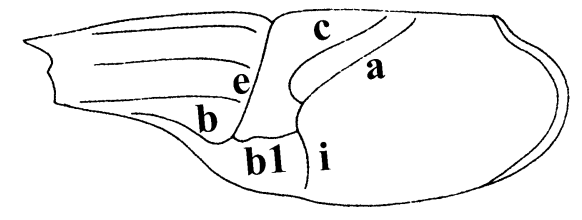

Glyphea

9.

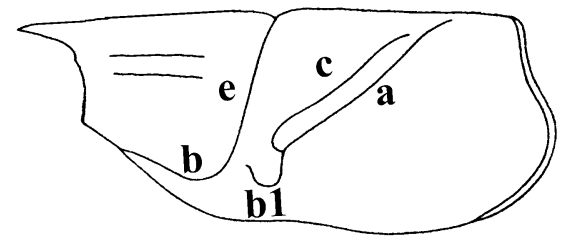

Pseudoglyphea
2.

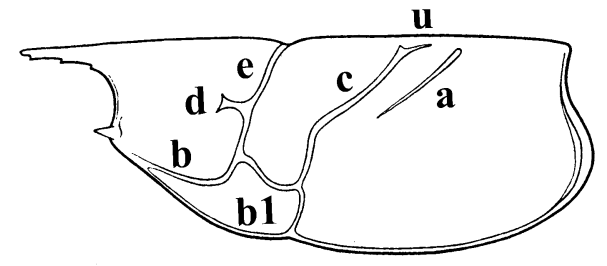

Phlyctisoma

4.

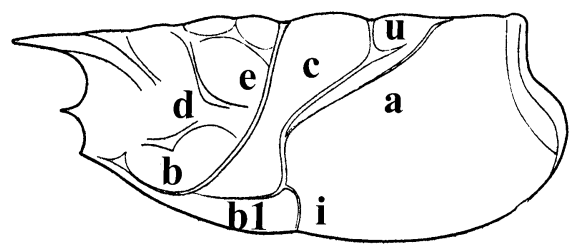

Pemphix

6.

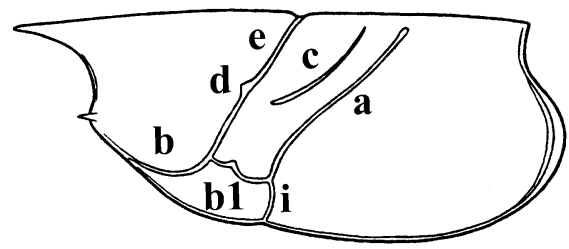

Clytiopsis

8.

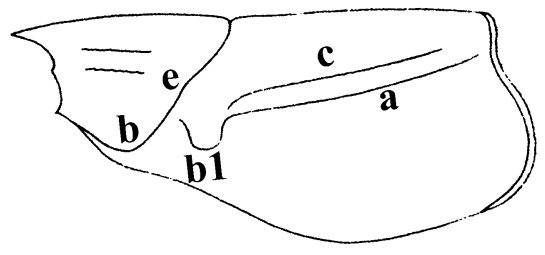

Mecochirus

10.

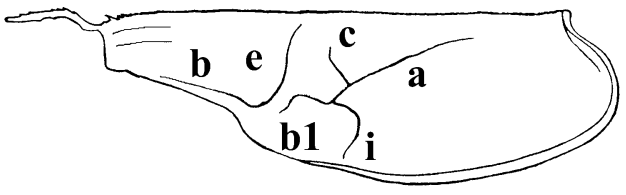

FIGURE 6-Line drawings of outgroup taxa and astacidean taxa used in cladistic analysis showing coding of groove patterns; a, branchiocardiac groove; b, antennar groove; c, postcervical groove; $d$, gastroorbital groove; e, cervical groove; $b_{1}$, hepatic groove; $c^{\prime}$, intercervical groove; i, inferior groove; u, urogastric groove; x, attachment site of adductor testis muscle. 1, Eryma, modified from Förster, 1966; 2, Phlyctisoma, modified from Förster, 1966; 3, Enoploclytia, modified from Förster, 1966; 4, Pemphix, modified from Förster, 1967; 5, Pseudopemphix, modified from Förster, 1967; 6, Clytiopsis, modified from Förster, 1966; 7, Glyphea, modified from Garassino, 1996; 8, Mecochirus, modified from Garassino, 1996; 
11.

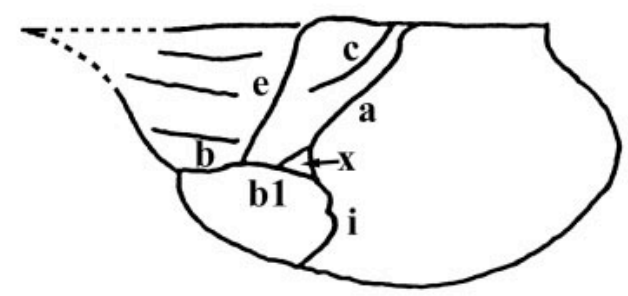

Chimaerastacus

13.

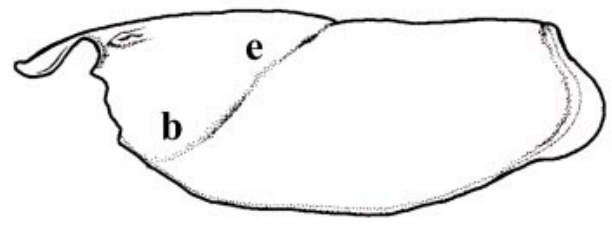

Cambarus

15.

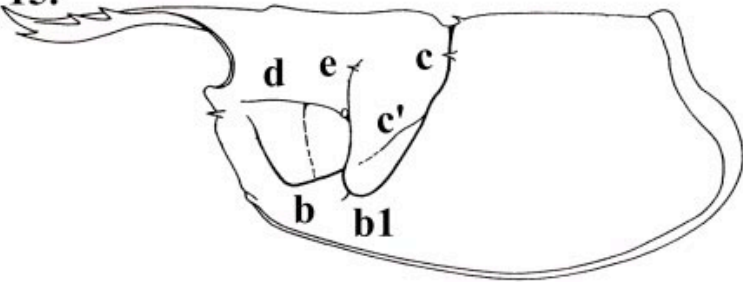

Nephrops

17.

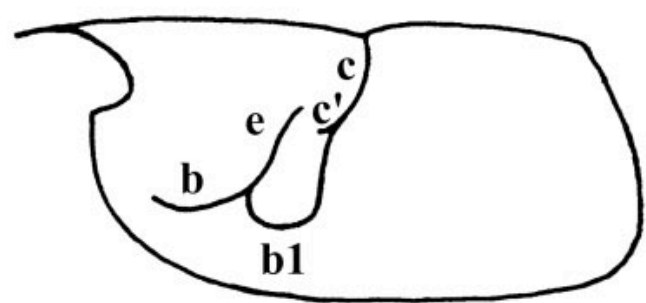

19.

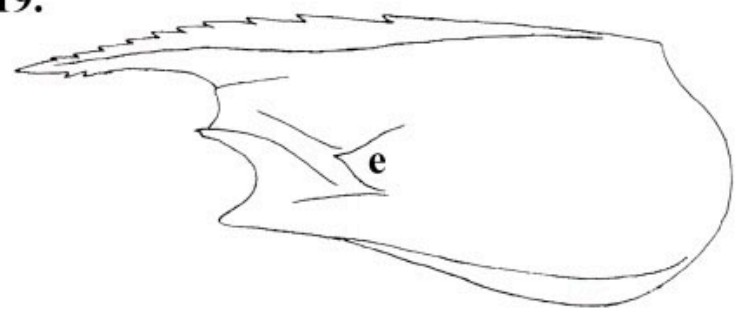

Penaeus
12.

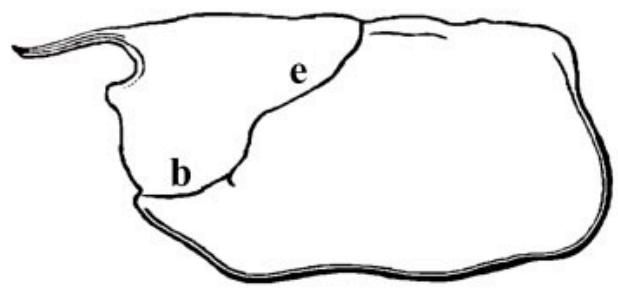

Astacus

14.

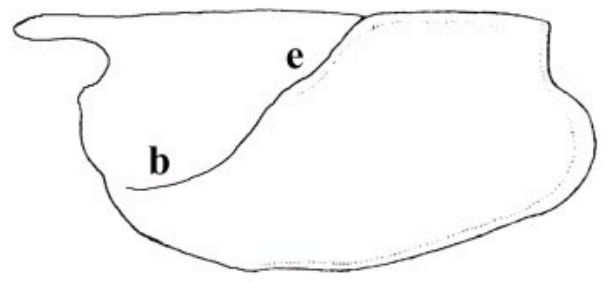

Virilastacus

16.

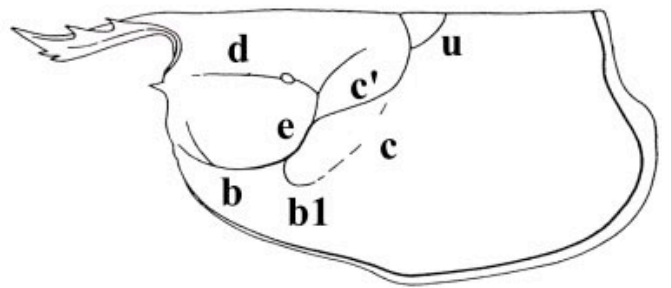

Homarus

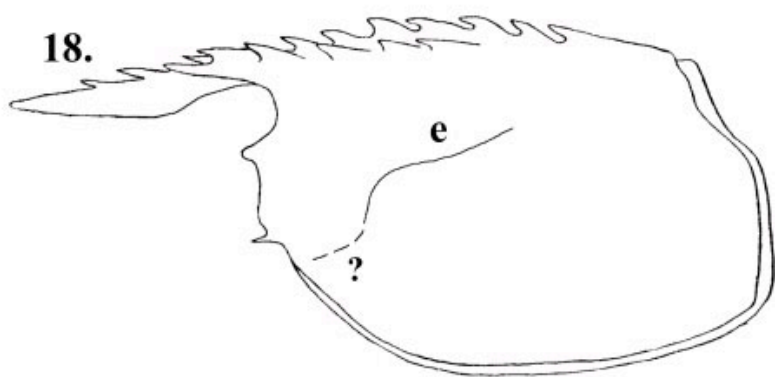

20.
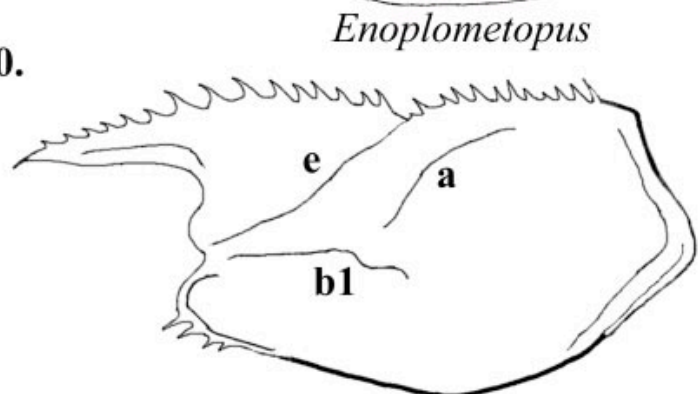

Stenopus

9, Pseudoglyphea, modified from Garassino and Teruzzi, 1993 and Garassino, 1996; 10, Neoglyphea, modified from Forest and de Saint Laurent, 1989; 11, Chimaerastacus; 12, Astacus, modified from Huxley, 1902; 13, Cambarus, modified from Bouchard and Bouchard, 1995; 14, Virilastacus, modified from Hobbs, 1991; 15, Nephrops, modified from Holthuis, 1974; 16, Homarus, modified from Holthuis, 1974; 17, Hoploparia, modified from Feldmann, 1974; 18, Enoplometopus, modified from Manning and Camp, 1989 and Kensley and Child, 1986; 19, Penaeus, modified from Williams, 1984; 20, Stenopus, modified from Abele and Felgenhauer, 1982. 


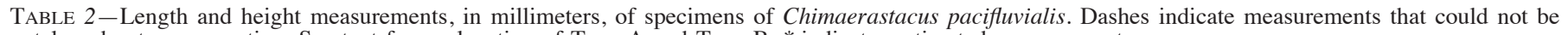
taken due to preservation. See text for explanation of Type A and Type B. * indicates estimated measurements.

\begin{tabular}{|c|c|c|c|c|c|c|c|c|c|c|c|c|}
\hline \multirow{2}{*}{$\begin{array}{c}\text { Specimen } \\
\text { number }\end{array}$} & \multicolumn{9}{|c|}{ Length } & \multicolumn{3}{|c|}{ Height } \\
\hline & 1 & 2 & 3 & 4 & 5 & 6 & 7 & 8 & 9 & $1 *$ & 2 & 3 \\
\hline \multicolumn{13}{|l|}{ Lateral View } \\
\hline \multicolumn{13}{|l|}{ Type A } \\
\hline 97.121 .015 & - & - & 13.5 & 10.2 & 9.3 & 5.8 & 4.2 & 7.8 & - & 11.8 & 8.6 & 7.4 \\
\hline 97.121 .034 & - & - & 10.7 & 7.6 & 7.0 & 5.1 & 3.8 & 7.7 & - & 10.4 & 7.9 & 7.0 \\
\hline 97.121 .572 & - & - & 9.4 & 6.9 & 6.1 & 4.1 & 3.2 & 5.3 & - & - & 7.0 & 6.2 \\
\hline \multicolumn{13}{|l|}{ Type B } \\
\hline 97.121 .543 & - & - & 14.2 & 10.7 & 10.0 & 3.8 & 1.8 & 5.5 & - & 11.6 & 7.8 & 6.9 \\
\hline 97.121 .007 & - & - & 8.7 & 6.7 & 5.5 & 3.1 & 1.8 & 4.5 & - & 7.9 & 5.4 & 4.5 \\
\hline 97.121 .524 & - & - & 10.3 & 7.8 & 6.8 & 2.5 & 1.6 & 4.1 & - & - & 6.0 & 5.2 \\
\hline \multicolumn{13}{|l|}{ Dorsal View } \\
\hline 97.121 .535 & 17.8 & 14.8 & 11.0 & 8.7 & 7.8 & - & - & - & 2.8 & - & - & - \\
\hline 97.121 .106 & 11.4 & 9.5 & 6.7 & 5.0 & 4.4 & - & - & - & - & - & - & - \\
\hline 97.121 .526 & 18.0 & 15.7 & 11.0 & 8.7 & 7.2 & - & - & - & - & - & - & - \\
\hline 97.121 .475 & 18.9 & 15.6 & 11.3 & 8.8 & 8.0 & - & - & - & - & - & - & - \\
\hline
\end{tabular}

Scholtz and Richter (1995) coined the term Fractosternalia for four of their monophyletic groups (Astacida, Thalassinida, Anomala and Brachyura) based on the separation of the eighth thoracic sternite from the rest of the sternum. This feature is present in crayfish, thalassinids, and anomalans but is presumably lost in brachyurans. The fractosternate condition is difficult to assess for

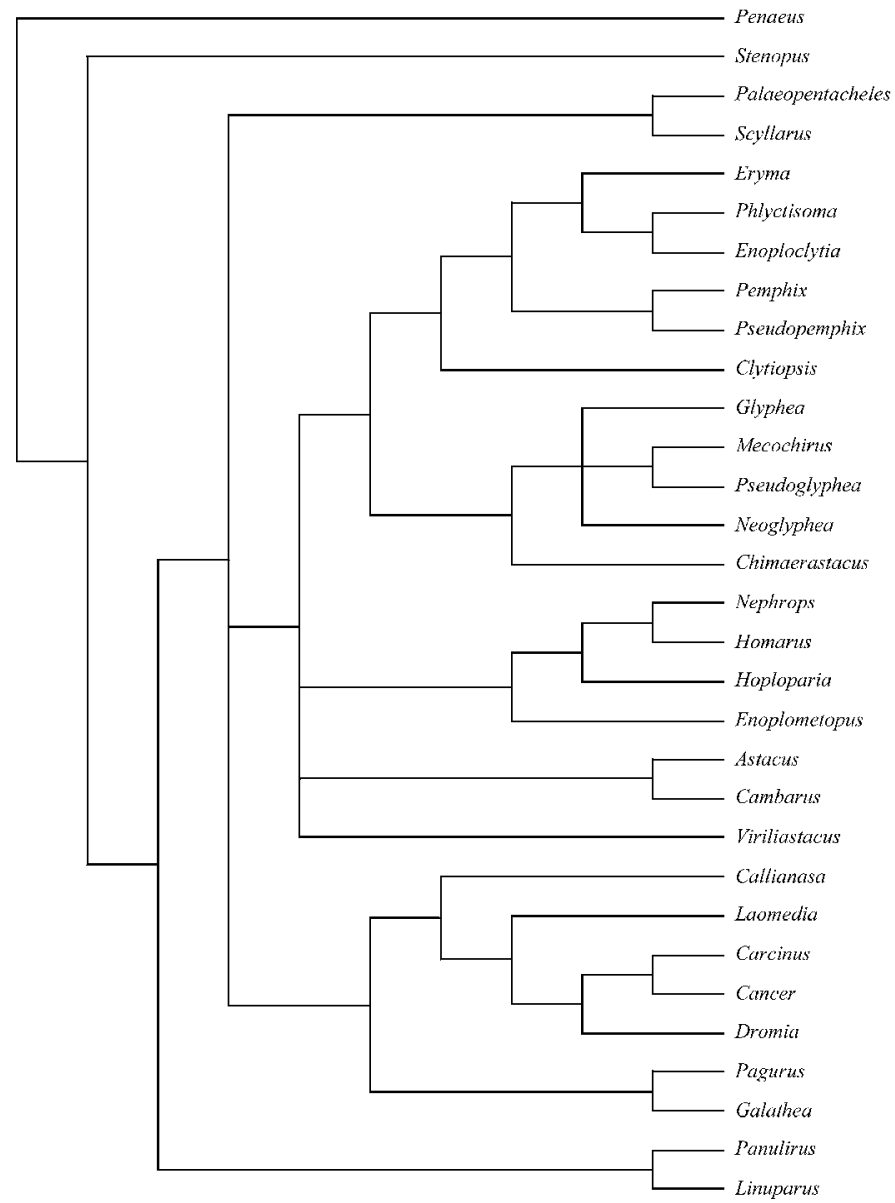

FIGURE 7-Strict consensus of five most parsimonious cladograms identified by PAUP* analysis. fossil lobsters, especially glypheids and erymids, which are preserved rarely in ventral view. We were able to code this feature only for modern taxa. Presence of the fractosternum arises at node 55 in our analysis and defines a clade that includes nephropoids, erymoids and glypheoids as well as groups included by Scholtz and Richter (1995). The topology requires reversals in the brachyura and the Nephropoidea. A free eighth thoracic sternite was recognized in Neoglyphea inopinata by Schram (2001) but the fractosternate condition is unknown for all other taxa above node 42. The results of our analysis predict the presence of a fractosternum in erymoids, but no direct fossil evidence confirms this. Because this character represents missing data for fossil taxa, we ran an identical analysis with the fractosternum excluded in order to determine the extent of the influence of this character on our result. Nodes 56, 55 and 54 collapsed as a result of the exclusion of the fractosternum, but the monophyly and ingroup relationships of the Astacidea were not affected.

A large clade composed of taxa from the infraorders Anomura, Thalassinidea, and Brachyura is defined at node 54. This group corresponds to the monophyletic Thalassinida-Anomala-Brachyura group in cladograms produced by Scholtz and Richter (1995) and Schram (2001). The purpose of including representatives of these taxa in our analysis is to allow an assessment of the monophyletic status of the Astacidea. Further investigation into the ingroup relationships of this clade will not be attempted here.

Our cladistic analysis agrees with the molecular analysis of Crandall and others (2001) by defining a monophyletic Astacidea, here diagnosed by the presence of a diaresis on the exopod of the uropod (character 19[1]) and a subcylindrical carapace cross section (character 1[2]). A diaresis is also present on the exopod in the Laomediidae and in some taxa in the Axiidae. The universal presence of this character in every taxon within the Astacidea and complete absence of a diaresis in all other taxa except for two highly derived families leads us to believe that it was derived independently in these groups and is a synapomorphy of the Astacidea. All three families of the superfamily Glypheoidea are firmly placed within the infraorder Astacidea, confirming the suggestion of Forest and de Saint Laurent (1989) and Martin and Davis (2001). It is our opinion that the taxa retained within the superfamily Glypheoidea may be incorporated into the infraorder Astacidea by emending the definition of the infraorder to include sub- to pseudochelate forms. This solution formalizes the suggestion made by Forest and de Saint Laurent that the Glypheoidea are more closely related to astacideans than to palinurans. Note, 
however, that contrary to Forest and de Saint Laurent (1989), we include the Mecochiridae within the superfamily.

Scholtz and Richter (1995) and Schram (2001) argue that nephropoids are not members of the Astacidea. Our analysis places them as a basal clade in the infraorder based on a cervical groove (e) that does not cross the midline of the carapace (character 7[0]) and the loss of the fractosternate condition (character 21[0]). Enoplometopus is defined by a lateral compression of the carapace (character 1[0]) and, in agreement with the suggestions of Forest and de Saint Laurent (1988), Schram (2001), and Martin and Davis (2001) forms a monotypic family. More than one family may be present within the Nephropoidea, as has been suggested by Tshudy and Babcock (1997) but details of phylogenetic relationships within this superfamily are not the focus of this paper.

The crayfishes form a paraphyletic group in the present analysis, and the relationships of the Astacoidea to other astacidean groups are not resolved. This is because morphological characters uniting astacid and parastacid crayfishes are not readily preserved in fossils so were not included in the analysis. For example, the suprabranchial groove is expressed mainly as a change in convexity of the carapace and is thus less likely to be preserved in fossil specimens. We feel that the question of monophyly of the crayfishes has been adequately dealt with by other workers (Scholtz, 1993, 1998, 1999; Crandall et al., 2000).

Node 42 describes the close relationship between erymoids and glypheoids based on carapace groove patterns. At node 41 , the superfamily Glypheoidea is the sister group to erymoids and is defined by the presence of cephalic ridges (character 4[1]). Chimaerastacus is a member of the monophyletic Glypheoidea, but lacks a laterally compressed carapace (character 1[0]), a postcervical groove (c) that arises from the branchiocardiac groove (a) (character 9[2]), and subchelae (character 13[1]) that make the family Glypheidae so distinctive. We therefore erect a new family, the Chimaerastacidae, which is defined by an attachment site of the adductor testis muscle ( $\mathrm{x}$ ) that is bounded by a ventral bifurcation of the branchiocardiac groove (a) (character 5[1]). We concur with Forest and de Saint Laurent (1989) that the Pemphicidae should not be classified with the glypheoids because our analysis indicates that they are related more closely to erymids than glypheoids. Pseudoglyphea and Mecochirus form a clade that is the sister group to both Glyphea and Neoglyphea, disputing the suggestion by Forest and de Saint Laurent (1989) that the mecochirids are not glypheids.

A suture along the midline of the carapace (character 2[1]) distinguishes the superfamily Erymoidea (node 38). Clytiopsis is the basal member of the group and, in the absence of other apomorphies, is a metataxon and can be treated as a potential ancestor (Gauthier et al., 1988). Clytiopsis and its relatives traditionally have been classified as a subfamily of the Erymidae; however, in order to maintain consistency of rank, we refer it here to the family Clytiopsidae.

The Pemphicidae (node 36) are the sister group to the Erymidae and are defined by the presence of a urogastric groove $(u)$ (character 6[1]) and a branchiocardiac groove (a) that arises from the postcervical groove (c) (character 8[3]). A fusiform intercalated plate at the anterior of the midline of the carapace (character $3[1])$ and presence of an intercervical groove $\left(c^{\prime}\right)$ (character 10[1]) define the Erymidae (node 35 ).

\section{SYSTEMATIC PALEONTOLOGY}

Order DECAPODA Latreille, 1802

Infraorder ASTACIDEA Latreille, 1802

Emended diagnosis.-Cephalothorax subcylindrical; rostrum and abdomen well developed; frontal portion of carapace not fused with epistome; antennae with five-segmented stalk and scale; third maxilliped pediform; pereiopods chelate, subchelate, or pseudochelate; first pereiopod longest; abdominal pleura well developed; exopods of uropods with diaresis; genital openings coxal.

Discussion.-Emending the diagnosis of the infraorder Astacidea to include sub- to pseudochelate forms allows inclusion of taxa traditionally classified in the superfamily Glypheiodea. Our cladistic analysis confirms that the taxa included form a solid clade based on the apomorphic presence of a diaresis on the exopod of the uropod. The epistome in this group meets the frontal portion of the carapace along a long edge of contact, but is not fused. This is in contrast to shrimp, in which the epistome meets the frontal portion of the carapace at a single point and is less calcified than the rest of the carapace. In the Palinura, as restricted herein, and Brachyura, the epistome is fused solidly to the carapace. This feature is difficult to code for most fossil taxa, so was not included in the present analysis. However, it does provide another apomorphic feature on which to base the diagnosis of the Astacidea.

\section{Family Chimaerastacidae new family}

Type genus.-Chimaerastacus pacifluvialis new genus and species by monotypy.

Diagnosis. Carapace subcylindrical, with distinct longitudinal ridges on anterior part; cervical, postcervical, and branchiocardiac grooves well defined and steeply inclined; branchiocardiac groove well developed; attachment site of adductor testis muscle well defined; median suture present; first through third pereiopods chelate.

Discussion-Chimaerastacus pacifluvialis possesses distinctive characteristics that preclude inclusion in any existing family within the Astacidea (Fig. 9). The longitudinal ridges on the cephalic region and the pattern of the cervical and branchiocardiac grooves bear a strong resemblance to the glypheids, but the presence of true chelae, subcylindrical cross section of the carapace and position of the postcervical groove prevents its inclusion in the family Glypheidae. The Chimaerastacidae possess several distinctive erymid characteristics such as the placement of the postcervical groove; possession of a median suture; and chelae on the first through third pereiopods. However, the chimaerastacids differ from typical genera within the superfamily Erymoidea in that they do not possess a small, fusiform, intercalated plate. The longitudinal ridges on the cephalic region further rule out inclusion within this clade.

\section{Genus Chimaerastacus new genus}

Type species.-Chimaerastacus pacifluvialis new species.

Diagnosis.-Branchiocaridac groove arises at hepatic region; postcervical groove arises at height of gastroorbital groove; region at attachment site of adductor testis muscle defined by ventral bifurcation of branchiocardiac groove.

Etymology.-The generic name reflects the presence of traits that are characteristic of two different families in a single taxon. In Greek mythology, a chimaera is any fabulous monster composed of body parts of more than one animal.

\section{ChimaERASTACUS PACIFLUVIALIS new species} Figures 9, 10, 11, Tables 1-2

Diagnosis.-Same as for genus.

Description.-Cephalothorax small in size, height about 60 percent of length excluding rostrum. Dorsal margin nearly straight; intercepts posterior margin at angle varying from 64 degrees to nearly 90 degrees; posterior margin strongly concave dorsally, very strongly convex at midheight with point of inflection at variable position, gently convex ventrally; posteroventral margin convex; anteroventral margin convex; anterior margin not 


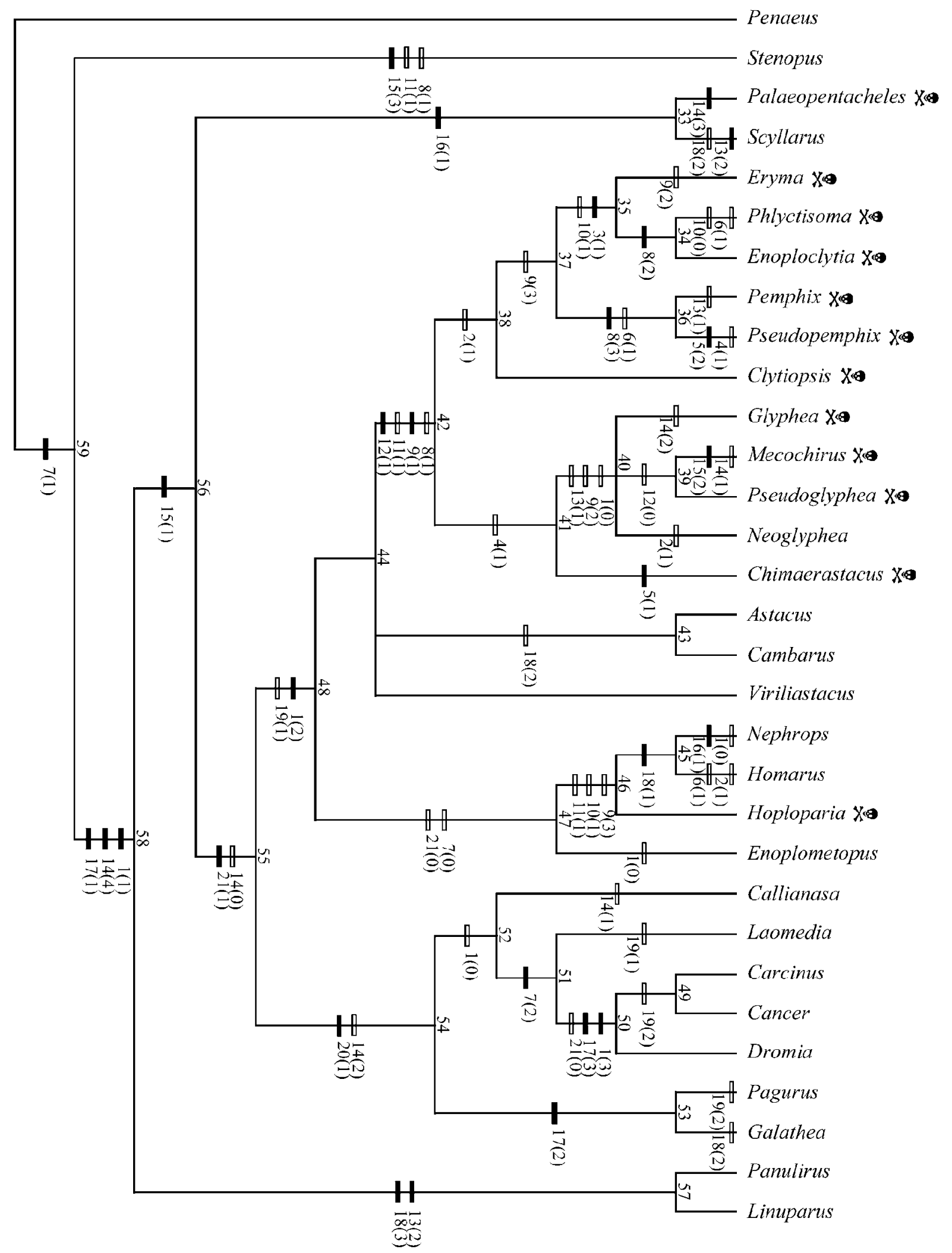

FIGURE 8-Optimized character distribution mapped onto one of the five most parsimonious cladograms, selected for optimum resolution. Open bars indicate character reversals. 
well preserved; rostrum straight, thin, smooth, sharp, about 16 percent total length, with keel along midline. Cervical groove wide, deeply incised, general inclination of groove at an angle ranging from 63 degrees to 83 degrees to the dorsum at an average distance of about 40 percent of total length of dorsal margin from anterior, broadens ventrally just dorsal to hepatic region into triangular shape, concave forward in specimens with more steeply inclined angles, weakly concave forward in specimens with more gentle groove slopes. Postcervical groove narrow, shallow, concave to weakly concave anterodorsally, subparallel to branchiocardiac groove for 75 percent of length, extends from dorsal margin about half the length of the branchiocardiac groove, curves toward cervical groove at height of inflection point in branchiocardiac groove, becomes less distinct and ends at elevation of supraorbital ridge, general trend of groove at an angle of 45-55 degrees to the dorsum at a distance of about 53 percent of total length of dorsal margin from anterior. Branchiocardiac groove deeply incised, wide over most of length, tapers near dorsum, sinuous to weakly sinuous, ventrally concave toward posterior, dorsally concave toward anterior, inflection point about halfway along length of groove, general trend of groove from center of attachment site of adductor testis muscle to intersection of groove with midline at an angle ranging from 51 to 67 degrees, more strongly sinuous branchiocardiac grooves found in individuals on which groove also tends to be more steeply inclined, intersects dorsum at average distance of 59 percent total length of dorsal margin from anterior. Inferior groove distinct and strongly concave toward anterior. Antennar groove distinct and weakly to very weakly concave ventrally. Raised region at attachment site of "adductor testis" muscle small, distinct, subcircular to subtriangular; bounded by branchiocardiac groove at posterior, inferior groove ventrally, and dorsal extension of antennar groove anteriorly. Cephalic region relatively short, subtriangular in shape; three subparallel carinae of about equal width ornamented with fine pustules extend nearly from anterior of cephalic region, broaden posteriorly to form elevated margin defining anterior margin of cervical groove, rostral and supraorbital ridges are closer together than supraorbital and antennar ridges; subtle swelling at posteroventral corner of cephalic region; small median dorsal ridge begins along rostrum and extends into cephalic region for a distance of 39 percent of cephalic region. Hepatic region obovate, nearly straight along dorsal margin, posterior margin strongly convex, ventral margin convex, higher in posterior, anterior margin shorter and rounded; moderately coarse pustules form longitudinal ridges near anterior of region, concentrically finely pustulose around dorsal and posterior margins, becoming granular toward center of region and at ventral margin. Region between branchiocardiac and postcervical grooves moderately coarsely pustulose anterodorsally, becoming nearly smooth toward posterior. Branchiostegite evenly and finely punctate, pustulose along ventral margin of branchiocardiac groove. Marginal rim distinct dorsally along midline posterior to branchiocardiac groove, continues around posterior then tapers at about midheight.

Endophragmal skeleton composed of series of dorso-ventrally aligned, subparallel elements, ventral margin longer than dorsal margin and generally convex. Six discrete thoracic somites visible. Pereiopods not attached in specimens.

Abdomen well developed; first somite reduced, about half as high as second, constricted at about one-third of length to form two distinct areas, articulating region small, ovoid, about threequarters as tall as posterior portion, posterior portion one-third longer, taller, more triangular in shape, pleuron greatly reduced, arcuate in outline, directed anteriorly; length of second somite less than subsequent somites, bears longest pleuron; third through fifth somites about equal length, pleura become progressively shorter until quite reduced in sixth somite. Tergal regions smooth, quadrate, bounded by shallow sulci, width of tergum of first somite least, width of tergum of second somite greatest, terga become progressively narrower from third through sixth somites; pleura well developed, smooth, antero- and posteroventral margins separated from medial region by sulci, pleural margins smoothly convex, directed posteriorly; telson poorly preserved, appears to be elongate, thin, tapers posteriorly, posterior termination broken; uropods well developed, flabellate, obovate, distal margin rounded, ornamented with distinct longitudinal ribs, diaresis on exopod of uropod.

Antennar and antennular bases about four times as long as high, number of segments indistinguishable in specimens; scaphocerite elongate and subtriangular, appears to be twice as long as high.

First pereiopod chelate, elongate, slender, enlarged relative to second through fifth pereiopods, coxa and basis not preserved; ischium about four times longer than high, narrows distally; merus about six times longer than high at greatest height, narrows at both extremities; carpus subrectangular, widens distally; propodus subrectangular proximally, ventral margin convex near articulation with carpus then nearly straight, weakly convex distally, dorsal margin nearly straight proximally, curves steeply at about half of length to become much thinner, fixed finger about equal to length of hand, slightly concave distally, extremity of appendage curves sharply upward to form pointed tip; dactylus thins toward distal end, dorsal margin slightly concave, occlusal surface convex over most of length curving to become concave at tip, two margins converge to form downturned, sharp point; fingers edentulous. Second and third pereiopods chelate, coxa and basis not preserved, ischium about four times longer than high, narrows distally; merus about six times longer than high at greatest height, narrows at both extremities; carpus about three times longer than high, nearly uniform in height for entire length; dactylus shortest element, upper margin slightly convex, lower margin slightly concave to form an arch; propodus thicker, subrectangular proximally, nearly triangular distally. Terminations of fourth and fifth pereiopods achelate. Pereiopods generally decrease in size posteriorly.

Measurements.-Measurements, in millimeters, are given in Tables 1 and 2 and orientations of measurements are shown in Figure 10.

Etymology.-The trivial name recognizes the discovery of these decapods near the Peace River.

Types.-Type specimens and all associated material is deposited in the Royal Tyrrell Museum, Alberta, Canada. Designated type specimens include the holotype, RTM 97.121.221, and paratypes, RTM 97.121.15, RTM 97.121.34, RTM 97.121.585, RTM 97.121.535, RTM 97.121.435, RTM 97.121.77.

Occurrence.-Specimens were collected from Aylard Creek, Brown Hill and Glacier Spur localities on Williston Lake from silty to sandy dolomitic limestone in the Liard Formation. Collected by researchers from the University of Alberta, the University of Calgary and Kent State University during the 1996-1999 field seasons. Conodont biozonation yields an age of upper Ladinian (Zonneveld, 1999).

Discussion.-The angle measurements listed in Table 1 were taken from the six specimens in lateral view that exhibited the least compressional distortion. Angles were measured from the center of the ventral margin of the groove to the intersection of the dorsal margin of the groove with the midline. This method provides a general trend of the groove and was used to avoid complications due to the highly sinuous or curved nature of the grooves. Specimens preserved in dorsal aspect do not provide reliable angle measurements. The same six individuals also were used for length measurements, given in Table 2. Height 1 is an 


\section{1}
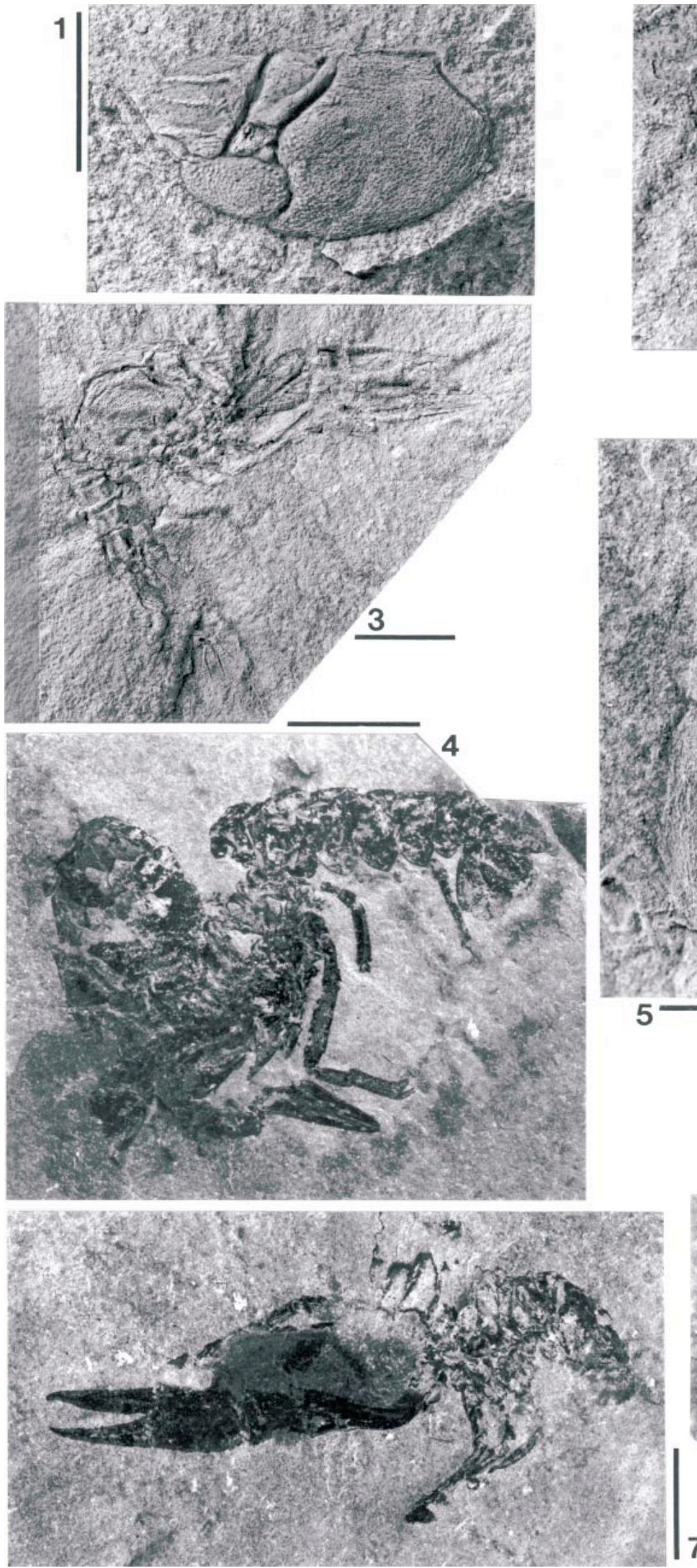
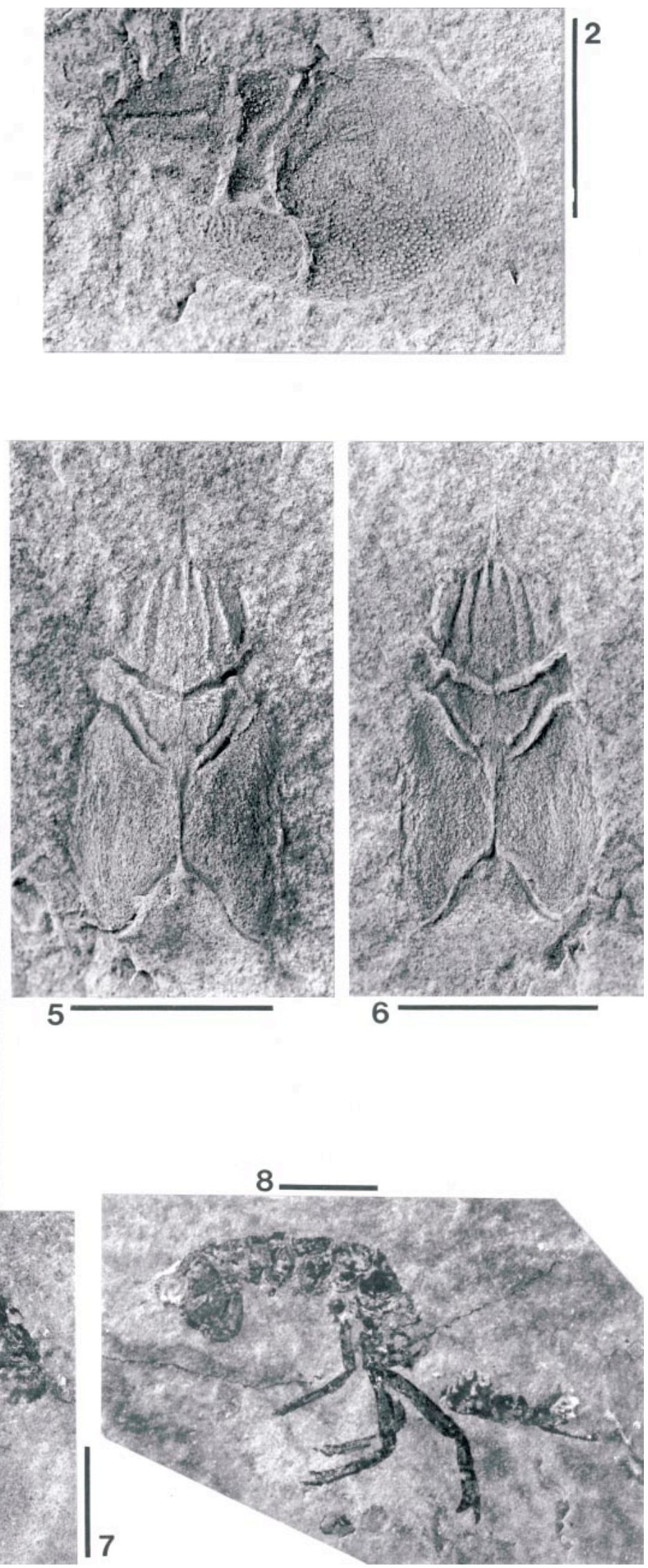
estimate of the total height of the carapace and cannot be determined with certainty because the poor quality of preservation makes the ventral margin difficult to ascertain. The intersection of the rostrum with the cephalic region can not be determined with certainty in lateral view as all of the specimens appear to be broken anteriorly. Four individuals were measured in dorsal view (Table 2). Only one rostrum is completely preserved; however, three specimens possess a partial rostrum that provides total length from the intersection of the rostrum with the cephalic region. Lengths 6,7 , and 8 could not be measured on specimens in dorsal view because the more ventral portions of the carapace are either not preserved or are distorted.

Two specimens (Figure 9.4 and 9.8) are preserved with a slight separation between pereiopods four and five, which suggests that this taxon possesses a fractosternum. However, because both of these specimens are molts, and none of the hundreds of specimens collected are preserved in ventral view, the evidence must be considered to be circumstantial.

A wide range of variation among individuals can be observed in the more than 500 specimens collected from the Williston Lake localities. The variation is most apparent in groove angles (Table 1). The specimens designated as Type A in Tables 1 and 2 and illustrated in Figure 11.1 have more gently inclined groove angles. The cervical groove is only very weakly concave forward and the branchiocardiac groove is less sinuous and curves toward the posterior more abruptly at the midline. The hepatic region in Type A is also more rounded in the anterior. Type B (Table 1, Fig. 11.2) has more steeply inclined groove angles. The cervical groove is much more markedly concave forward, and the branchiocardiac groove is more highly sinuous. The anterior margin of the hepatic region in Type B is less rounded. The two types cannot be distinguished in dorsal view as preservational bias renders the groove angles unreliable. Figure 11.3 illustrates these differences by overlaying the two variations in carapace ornamentation. Type A is drawn with a solid line and Type B is represented by the dotted line.

The differences observed between individual specimens of the sample are not significant enough to warrant the designation of two separate species. The variations are most apparent in groove angles, which delineate the general internal anatomy of the animals and therefore do not appear to represent sexual dimorphism. The diversity observed in this sample is explained best as variation within a species.

\section{PALEOECOLOGY}

Continental reconstructions for the Middle Triassic estimate the paleolatitude near the Peace River Embayment to be 30 degrees North (Habicht, 1979; Wilson et al., 1991) (Fig. 12). Upper Triassic (Carnian) deposits in the Western Canada Sedimentary Basin contain abundant evaporites (Gibson and Barclay, 1989; Zonneveld et al., 2001). Evaporite minerals are a common component of the upper Ladinian to lower Carnian Charlie Lake Formation (Zonneveld et al., 2001). This unit overlies and intertongues extensively with the Liard Formation. Although evaporite minerals were not observed in the study area, their deposition is inferred

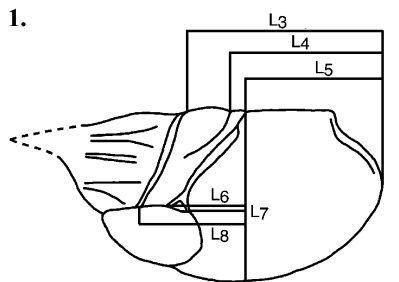

2.

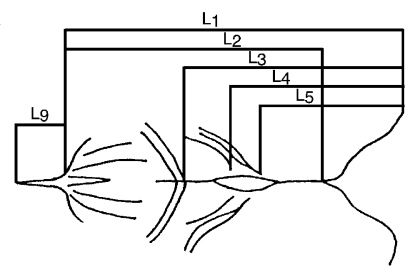

FIGURE 10-Line drawing of a chimaerastacid and designation of measurements taken. Length 1 , intersection of rostrum with cephalic region to posterior margin. Length 2, intersection of rostrum with cephalic region to notch at intersection of dorsal margin with posterior margin. Length 3 , intersection of cervical groove with midline to posterior margin. Length 4 , intersection of postcervical groove with midline to posterior margin. Length 5, intersection of branchiocardiac groove with midline to posterior margin. Length 6 , intersection of branchiocardiac groove with antennar groove to perpendicular from intersection of branchiocardiac groove with midline. Length 7, intersection of branchiocardiac groovee with inferior groove to perpendicular from intersection of branchiocardiac groove with midline. Length 8 , intersection of cervical groove with antennar groove to perpendicular from intersection of branchiocardiac groove with midline. Length 9, length of rostrum from tip to intersection with cephalic region. Height 1 , estimated length of line perpendicular to midline, from intersection of branchiocardiac groove with midline to ventral margin. Height 2, intersection of branchiocardiac groove with midline to intersection of branchiocardiac groove with antennar groove. Height 3 , intersection of cervical groove with midline to intersection of cervical groove with antennar groove.

by the presence of several thick and laterally extensive solution collapse breccias (Zonneveld et al., 2001).

Paleoclimate models suggest seasonally variable onshore upwelling of cold water near the Peace River Basin in the Middle Triassic (Golonka et al., 1994) (Fig. 12). This pattern of ocean circulation, coupled with north to northeast tradewinds, led to climatic aridity along the northwestern Pangean coastline (Gonlonka et al., 1994). High evaporation rates, limited rainfall, cyclonic storms, strong winds and severely constrained sediment delivery to the coastal zone combine to produce a unique amalgamation of siliciclastic, bioclastic, and chemical sediments in arid coastal settings (Semeniuk, 1996). These climatic parameters are interpreted to have had a pronounced effect on deposition in the study interval (Arnold, 1994; Davies, 1997; Zonneveld et al., 2001). Rainfall in arid regions is typically seasonal and often intense and may carry an atypically high sediment load, due in part to sparse vegetation in sediment source areas (Semeniuk, 1996). Within the study area, fluvial transport of terrigenous sediment to the shore zone was ephemeral, likely limited primarily to flash floods associated with cyclonic storms (Davies, 1997; Zonneveld et al., 2001).

The diversity of the fauna preserved in the upper Liard Formation suggests that normal, fully marine conditions were dominant in the Ladinian. Numerous taxa of bivalves have been recovered, most of which have yet to be identified. Echinoid and crinoid fragments are preserved on a number of bedding planes,

FIGURE 9-Chimaerastacus pacifluvialis new genus and species, from northeastern British Columbia, Canada. 1, Left lateral view of cephalothorax $($ RTM 97.121.15) $\times 2.4$. 2, Mold of right lateral portion of cephalothorax $($ RTM 97.121.34) $\times 3.0$. 3, Right lateral view of nearly complete specimen $($ RTM 97.121.221) ×1.5. 4, Left lateral view of carapace, internal skeleton, abdomen and pereiopod fragments $($ RTM 97.121.585) $\times 2.0 .5$, Dorsal view of cephalothorax (RTM 97.121.535) ×3.0.6, Mold of dorsal view of cephalothorax (RTM 97.121.535) $\times 3.0$. 7, Left pereiopod and left lateral view of internal skeleton, anterior portion of abdomen, and fragments of second through fourth pereiopods (RTM 97.121.435) $\times 1.7 .8$, Right lateral view of abdomen, second through fifth pereiopods, and fragment of first pereiopod (RTM 97.121.77) $\times 1.5$. RTM $=$ Royal Tyrrell Museum. 
1.

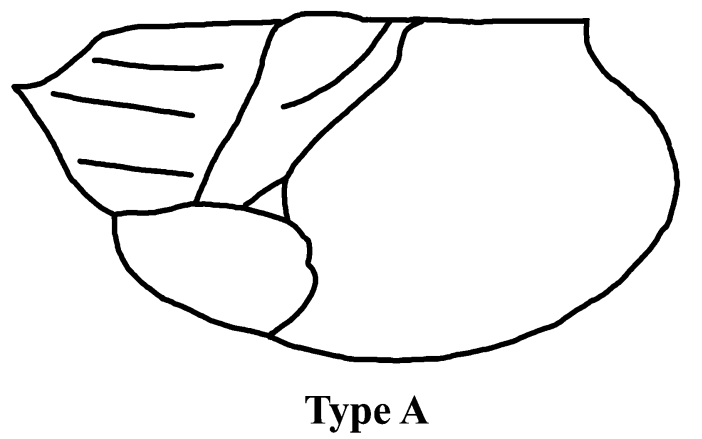

2.

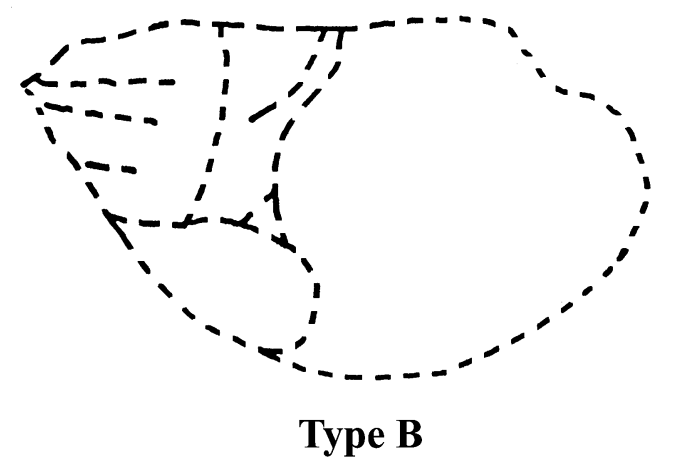

3.

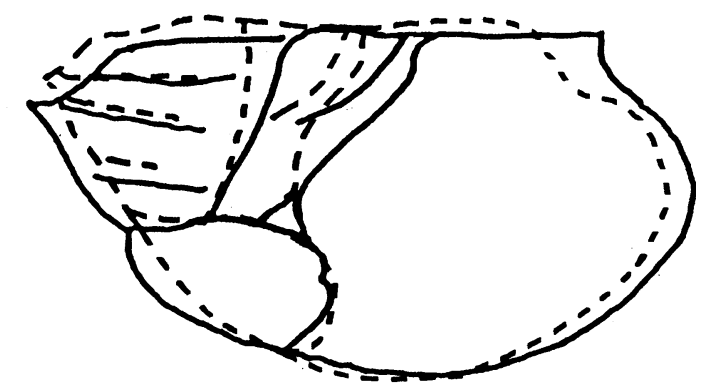

FIGURE 11-Line drawings illustrating the variation among individuals within the sample. 1, Type A. Groove angles more gently inclined, cervical groove weakly concave forward, branchiocardiac groove less sinuous, hepatic region with rounded anterior. 2, Type B. Groove angles more steeply inclined, cervical groove strongly concave forward, branchiocardiac groove more sinuous, anterior margin of hepatic region sharper. 3, Overlay of Type A (solid line) over Type B (dotted line).

indicating normal salinity levels (Zonneveld, 2001). Discinid and terebratulid brachiopods are found throughout the section. The terebratulids are also found as a component of bioclastic mounds along with echinoid remains (Zonneveld, 2001). Vertebrate remains include isolated skeletal elements and tooth plates of palaeonisciform and actinopterygian fish, as well as body fossils of ichthyosaurs and other marine reptiles. Although abundant and diverse elsewhere in the Liard Formation, trace fossils within the decapod layer are limited to isolated specimens of Planolites montanus (Zonneveld, 1998).

At least two taxa of decapod crustaceans are present in the upper Liard Formation. In addition to $C$. pacifluvialis, a single, poorly preserved carapace of another decapod taxon was collected from Williston Lake. Orbital and marginal spines on the carapace outline and a slight dorsoventral compression of the carapace suggest affinities with the superfamily Eryonoidea, but no formal identification has yet been made. In addition to the decapod crustaceans discovered at Williston Lake, a single, partial phyllocarid also has been collected. Although the carapace is preserved in detail, the specimen currently remains unidentified. Phyllocarids are typical of Paleozoic rocks and are rare in the Triassic. It is also highly unusual to discover these Paleozoic relics associated with decapods as they normally inhabit different environments. The presence of two decapod taxa in association with a phyllocarid represents remarkable diversity for a Middle Triassic locality.

The decapods of the upper Liard Formation inhabited a transitional environment between terebratulid/echinoid reef mounds and the main shoreface (Zonneveld, 1998). The host lithology consists of bioclastic silt and siliciclastic sand, characteristic of deposition in a biostrome flank setting (Zonneveld et al., 1997b). The decapod remains are oriented randomly and are preserved as nearly complete body fossils, nearly complete molts and as isolated body fragments. This evidence suggests that the crustaceans were living near mean fairweather wave base and were not subjected to significant transport prior to burial.

The extraordinary abundance of decapod remains warrants examination. Crustaceans are a delicacy for many fish species, and the actinopterygian tooth plates found in the decapod strata are characteristic of predators on hard-shelled organisms (Zonneveld et al., 1997b). Decapod molts are also highly desired food items to many other predators and scavengers, especially cephalopods (Tshudy et al., 1989), and to the decapods themselves, which reingest the discarded carapace material to facilitate the secretion of a new shell. Therefore, it is rare for decapod remains to be preserved and their abundance is typically low. The decapod unit in British Columbia is an extraordinary exception to this general rule. The abundance and quality of preservation in this area can be attributed to the specialized environment in which they lived. Terebratulid/echinoid reef mounds provided a buffer from the strong waves of the open ocean, which prevented disarticulation of many whole specimens (Zonneveld et al., 1997b). Bioclastic silt carried over the biostromes during storm events settled quickly to bury some individuals before they could be scavenged. Siliciclastic sand brought from shore during seasonal continental flooding or storm events and which accumulated behind the reef was probably deposited as thick sheets that facilitated preservation.

\section{CONCLUSIONS}

The decapod fauna from the Liard Formation in British Columbia is exceptional. With hundreds of specimens already collected, the fauna contains one of the greatest number of Triassic lobster fossils ever found in one area. Many nearly complete specimens have been collected, and nearly every preservable body part is represented. Although the fossils were slightly compressed upon burial, remarkable detail has been preserved, including carapace ornamentation. The discovery of these new specimens and recognition of the new family Chimaerastacidae adds to our knowledge of the history of lobsters in North America. Only four genera, represented by fragmentary material, had been described previously from the Triassic. Our phylogenetic analysis demonstrates that glypheoids are legitimate members of the infraorder Astacidea and defines their relationship to other taxa within the clade. The family Chimaerastacidae emerges as a basal member of the glypheids and Clytiopsis is identified as a possible ancestor to the erymids, including the pemphicids. The paleoecology of $C . p a-$ cifluvialis illuminates the role of crustaceans in a shallow marine environment during the recovery period following the end-Permian extinction. 

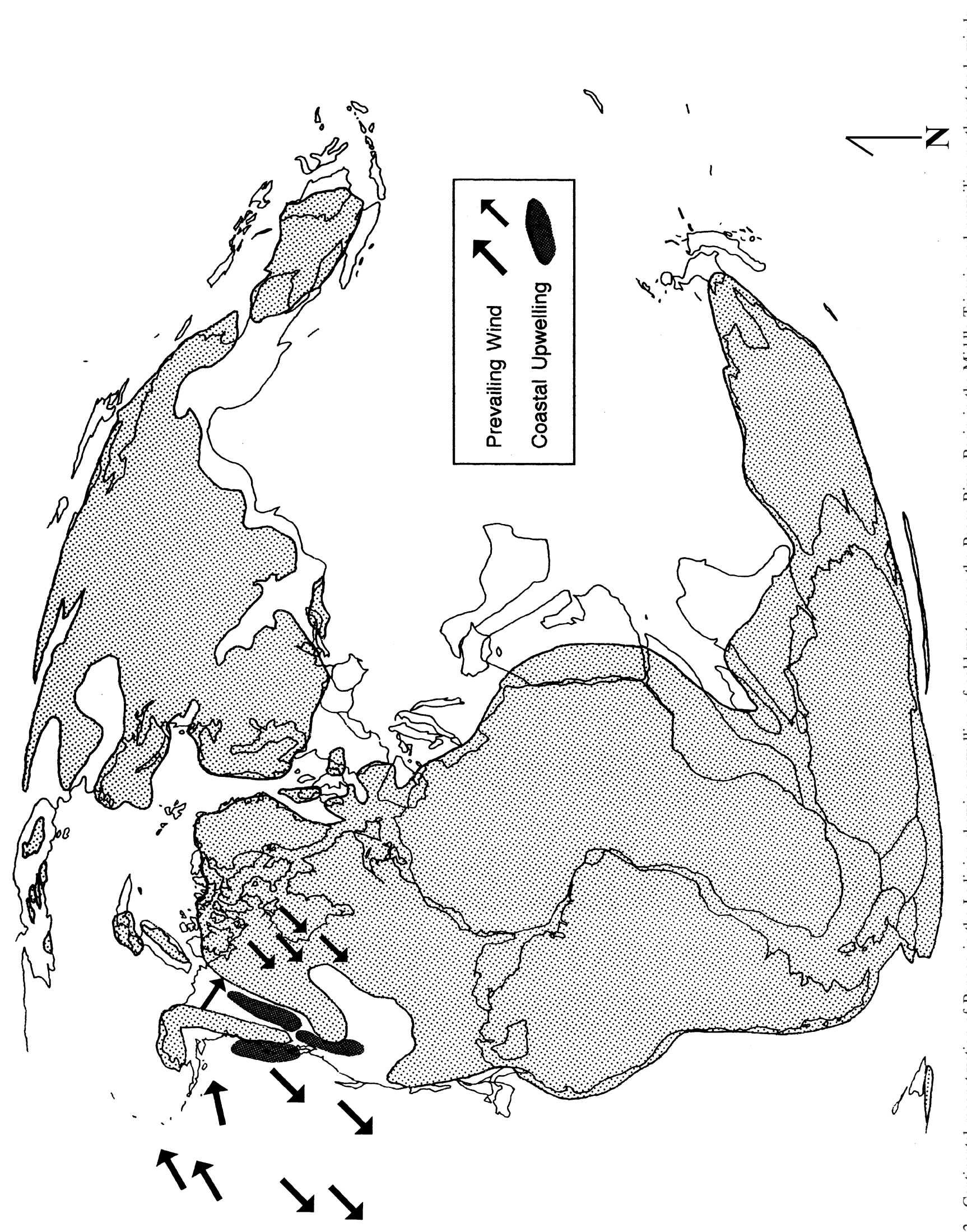


\section{ACKNOWLEDGMENTS}

We would like to thank K. D. Brett, B. J. Blakney, and S. Zaklan for making preliminary collections and M. K. Gingras and T. D. A. Saunders for their assistance with the stratigraphic and sedimentologic analyses. Biostratigraphic data were supplied by C. M. Henderson, M. J. Orchard and E. T. Tozer. A. Garassino and R. Lupia reviewed a preliminary draft of the manuscript. The manuscript was significantly improved by reviews by A. Garassino, F. Schram and G. Scholtz. The cladistic analysis was made possible through the suggestions of S. Westrop. Fieldwork was supported in part by grants from Petro Canada Resources and Canadian Hunter Exploration Limited to J.-P. Z., the Kent State University Research Council to R. M. F. and an Amoco Alumni scholarship to L. A.

\section{REFERENCES}

Abele, L. G., AND B. E. Felgenhauer. 1982. Decapoda, p. 296-326. In S. P. Parker (ed.), Synopsis and Classification of Living Organisms. McGraw-Hill, New York.

AlbRecht, H. 1981. Zur deutung der carapaxfurchen der Astacidea (Crustacea, Decapoda). Zoologica Scripta, 10:265-271.

ARNOLD, K. J. 1994. Origin and distribution of aeolian sandstones in the Triassic Charlie Lake Formation, northeastern British Columbia. Unpublished Master's Thesis, University of Alberta, Edmonton, Canada, $320 \mathrm{p}$.

BIRSTEIN, J. A. 1958. Drevneyshy predstavitel' otryada desyatinogikh rakoobraznykh Protoclytiopsis antiqua gen. nov. sp. nov. iz Permskikh otlozheniy zapadnoy Sibiri. Doklady Akademii nauk SSSR, 122(3): 477-480.

Bouchard, R. W., AND J. W. Bouchard. 1995. Two new species and subgenera (Cambarus and Orconectes) of crayfishes (Decapoda: Cambaridae) from the eastern United States. Notulae Naturae of the Academy of Natural Sciences of Philadelphia, 471:1-21.

COPE, E. D. 1871. On three extinct astaci from the fresh-water territory of Idaho. Proceedings of the American Philosophical Society, 11:605-607.

Crandall, K. A., D. J. Harris, and J. W. Fetzner. 2000. The monophyletic origin of freshwater crayfish estimated from nuclear and mitochondrial DNA sequences. Proceedings of the Royal Society of London, B, 267:1679-1686.

Davies, G. R. 1997. The Triassic of the western Canada Sedimentary Basin: tectonic and stratigraphic framework, paleogeography, paleoclimate and biota. Bulletin of Canadian Petroleum Geology, 45(4):434-460.

Donoghue, M. J., J. A. Doyle, J. Gauthier, A. G. Kluge, and R. ROWE. 1989. The importance of fossils in phylogeny reconstruction. Annual Review of Ecology and Systematics, 20:431-460.

FeldManN, R. M. 1974. Hoploparia riddlensis, a new species of lobster (Decapoda: Nephropidae) from the Days Creek Formation (Hauterivian, Lower Cretaceous) of Oregon. Journal of Paleontology, 48:586-593.

Feldmann, R. M., AND M. DE SAint LAUREnT. 2002. Glyphea foresti n. sp. (Decapoda) from the Cenomanian of Northern Territory, Australia. Crustaceana, 75:359-373.

Feldmann, R. M., G. A. Bishop, And T. W. Kammer. 1977. Macrurous decapods from the Bearpaw Shale (Cretaceous: Campanian) of northeastern Montana. Journal of Paleontology, 51(6):1161-1180.

Feldmann, R. M., L. Grande, C. P. Berkhimer, J. T. Hannibal, and D. L. McCoy. 1981. Decapod fauna of the Green River Formation (Eocene) of Wyoming. Journal of Paleontology, 55:788-799.

ForEST, J., AND M. DE SAINT LAURENT. 1981. La morphologie externe de Neoglyphea inopinata, espèce actuelle de Crustacé Décapode Glyphéide. Résultats des Campagnes MUSORSTOM, Volume 1. Mémoires Muséum National d'Histoire Naturelle, 91:51-84.

Forest, J., AND M. DE SAINT LAURENT. 1989. Nouvelle contribution à la connaissance de Neoglyphea inopinata Forest and de Saint Laurent, à propos de la description de la femelle adulte. Résultats des Campagnes MUSORSTOM, Volume 5. Mémoires Muséum National d'Histoire Naturelle, (A), 144:75-92.

FÖRSTER, R. 1966. Über die Erymiden, eine alte konservative familie der mesozoischen dekapoden. Palaeontographica, 125:61-125.

FÖRSTER, R. 1967. Die reptantan dekapoden der Trias. Neues Jahrbuch Geologie und Paläontologie Abhandlung, 128(2):136-194.

Garassino, A. 1996. The family Erymidae Van Straelen, 1924 and the superfamily Glypheoidea Zittel, 1885 in the Sinemurian of Osteno in Lombardy (Crustacea, Decapoda). Atti Societa Italia Scienze Nationale Museo Civico Storio Naturale Milano, 135:333-373.

Garassino, A., AND G. TeruZZi. 1993. A new decapod crustacean assemblage from the Upper Triassic of Lombardy (N. Italy). Paleontologia Lombarda, Nuova Serie, 1:3-27.

Gauthier, J., A. Kluge, And T. Rowe. 1988. Amniote phylogeny and the importance of fossils. Cladistics, 4:105-209.

Gemmellaro, G. G. 1890. Crostacei dei calcari con Fusulina della Valle del Fiume Sosio, nella Provicia di Palermo in Sicilia. Societa Italiana Scienze Memorie, 3(8):1-40.

GiBson, D. W. 1975. Triassic rocks of the Rocky Mountain foothills and front ranges of northeastern British Columbia and west-central Alberta. Geological Survey of Canada, 247:1-61.

GiBSON, D. W., AND J. E. BARClay. 1989. Middle Absaroka sequence: The Triassic stable craton, p. 219-231. In B. D. Ricketts (ed.), Western Canada Sedimentary Basin: A Case History. Canadian Society of Petroleum Geologists, Calgary.

GLAESSNER, M. F. 1960. The fossil decapod Crustacea of New Zealand and the evolution of the Order Decapoda. Paleontological Bulletin, 31:1-79.

Glaessner, M. F. 1969. Decapoda, p. R400-566. In R. C. Moore (ed.), Treatise on Invertebrate Paleontology, Pt. R, Arthropoda 4. Geological Society of America and University of Kansas Press, Lawrence.

GolonKA, J., M. I. Ross, AND C. R. SCOTESE. 1994. Phanerozoic paleogeographic and paleoclimatic modeling maps, p. 1-47. In A. F. Embry and D. J. Glass (eds.), Pangea: Global Environments and Resources. Canadian Society of Petroleum Geologists, Memoir 17.

HАBicht, J. K. A. 1979. Paleoclimate, paleomagnatism, and continental drift. American Association of Petroleum Geologists Studies in Geology, 9:1-29.

Hasiotis, S. T., AND C. E. Mitchell. 1989. Lungfish burrows in the Upper Triassic Chinle and Dolores formations, Colorado Plateau-Discussion: new evidence suggests origin by a burrowing decapod crustacean. Journal of Sedimentary Petrology, 59:871-875.

HoBBS, H. H., JR. 1991. A new generic assignment for a South American crayfish (Decapoda: Parastacidae) with revised diagnoses of the South American genera and comments on the parastacid mandible. Proceedings of the Biological Society of Washington, 104(4):800-811.

Holthuis, L. B. 1974. The lobsters of the superfamily Nephropidea of the Atlantic Ocean (Crustacea: Decapoda). Bulletin of Marine Science, 24(4):723-871.

HuXLEY, T. H. 1902. An Introduction to the Study of Zoology, Illustrated by the Crayfish. D. Appleton and Company, New York, 370 p.

Kensley, B., AND C. A. ChILD. 1986. A new species of Enoplometopus (Thalassinidea: Axiidae) from the northern Phillipines. Journal of Crustacean Biology, 6(3):520-524.

LATREILLE, P. A. 1802-1803. Histoire naturelle, général et particulière, des crustacés et des insectes, Volume 3. F. Dufart, Paris, 468 p.

MANNING, R. B., AND D. K. CAMP. 1989. Additional records for an Atlantic reef lobster, Enoplometopus antillensis Lütken, 1865 (Crustacea, Decapoda, Enoplometopidae). Proceedings of the Biological Society of Washington, 102(2):411-417.

Martin, J. W., AND G. E. DAvis. 2001. An updated classification of he Recent Crustacea. Natural History Museum of Los Angeles County, Science Series, 39:1-124.

MilleR, G. L., AND S. R. Ash. 1988. The oldest freshwater decapod crustacean, from the Triassic of Arizona. Paleontology, 31:273-279.

Mosher, L. C. 1973. Triassic conodonts from British Columbia and the northern Arctic Islands. Geological Survey of Canada Bulletin, 222: 141-192.

O'Leary, M. A., And J. H. Geisler. 1999. The position of Cetacea within Mammalia: phylogenetic analysis of morphological data from extinct and extant taxa. Systematic Biology, 48(3):455-490.

ORCHARD, M. J., AND E. T. TOZER. 1997. Triassic conodont biochronology, its calibration with the ammonoid standard, and a biostratigraphic summary for the Western Canada Sedimentary Basin. Bulletin of Canadian Petroleum Geology, 45(4):675-692.

SAINT LAURENT, M. DE. 1988. Enoplometopoidea, nouvelle superfamille de Crustacés Décapodes Astacidea. Comptes Rendus Hebdomadaires des Seances de 1'Academie des Sciences, series 3, 307:59-62.

ScHOLTZ, G. 1993. Teloblasts in decapod embryos: an embryonic character reveals the monophyletic origin of freshwater crayfishes (Crustacea: Decapoda). Zoologischer-Anzeiger, 230(1-2):45-54. 
Scholtz, G. 1998. Von Zellen und Kontinenten-die Evolution der Flußkrebse (Decapoda, Astacida). Stapfia, 58:205-212.

SchOlTZ, G. 1999. Freshwater crayfish evolution. Freshwater Crayfish 12, Proceedings of the Twelfth Symposium of the International Association of Astacology:36-48.

Scholtz, G., AND S. Richter. 1995. Phylogenetic systematics of the reptantian Decapoda (Crustacea, Malacostraca). Zoological Journal of the Linnean Society, 113:289-328.

Schram, F. R. 1971. Litogaster turnbullensis (sp. nov.): a Lower Triassic glypheid decapod crustacean from Idaho. Journal of Paleontology, 45(3):534-537.

SCHRAM, F. R. 2001. Phylogeny of decapods: moving toward a consensus. Hydrobiologia, 449:1-20.

SeCRETAN, S. 1973. A propos des sillons et d'une mandibule apparente sur des spécimens nouveaux de Pseudoglyphea etalloni Oppel. Annales de Paléontologie, 59:187-201.

SEMENIUK, V. 1996. Coastal forms and Quaternary processes along the arid Pilbara coast of northwestern Australia. Palaeogeography, Palaeoclimatology, Palaeoecology, 123:49-84.

Smith, A. G., A. M. Hurley, And J. C. Briden. 1981. Phanerozoic Paleocontinental World Maps, Cambridge University Press, Cambridge, p. $56-57$.

Smith, A. G., D. G. Smith, And B. M. Funnell. 1994. Atlas of Mesozoic and Cenozoic Coastlines, Cambridge University Press, Cambridge, $53 \mathrm{p}$.

SwofFord, D. L. 2000. PAUP*. Phylogenetic Analysis Using Parsimony Version 4. Sinauer Associates, Sunderland, Massachusetts.

Tozer, E. T. 1994. Canadian Trissic ammonoid faunas. Geological Survey of Canada Bulletin, 467:1-663.

Tshudy, D. M., AND L. E. BABCOCK. 1997. Morphology-based phylogenetic analysis of the clawed lobsters (family Nephropidae) and the new family Chilenophoberidae. Journal of Crustacean Biology, 17(2): 253-263.

Tshudy, D. M., R. M. Feldmann, AND P. D. Ward. 1989. Cephalopods: biasing agents in the preservation of lobsters. Journal of Paleontology, 63(5):621-626.

VAn StRaelen, V. 1936. Sur des crustacés dédapodes Triasiques du Nevada. Bulletin du Musée Royal d'Histoire Naturelle de Belgique, 12(29): $1-7$

Williams, A. B. 1984. Shrimps, Lobsters, and Crabs of the Atlantic Coast of the Eastern United States, Maine to Florida. Smithsonian Institution Press, Washington D. C., 550 p.

Wilson, K. M., W. W. HAY, AND C. N. WOLD. 1991. Mesozoic evolution of exotic terranes and marginal seas, western North America. Marine Geology, 102:311-361.

ZONNEVELD, J.-P. 1998. Sequence stratigraphic and depositional framework of the lower-middle Triassic succession, Williston Lake, NE British Columbia. Field Trip Guidebook, May 25-28 1998, Applied Stratigraphic Research Group, Calgary, Alberta, Canada, 134 p.

ZONNEVELD, J.-P. 1999. Sedimentology and sequence biostratigraphic framework of mixed siliciclastic-carbonate depositional system, Middle Triassic, northeastern British Columbia. Unpublished Ph.D. Dissertation, University of Alberta, $287 \mathrm{p}$.

ZoNNEVELD, J.-P. 2001. Middle Triassic biostromes from the Liard Formation, British Columbia, Canada: oldest examples from the Mesozoic of NW Pangea. Sedimentary Geology, 145:317-341.

Zonneveld, J.-P., M. K. Gingras, and S. G. Pemberton. 2001. Depositional framework and trace fossil assemblages in a mixed siliciclastic-carbonate marginal marine depositional system, Middle Triassic,
NE British Columbia. Palaeogeogrphay, Palaeoclimatology, Palaeoecology, 166:249-276.

ZonNeVELD, J.-P., T. F. Moslow, AND M. K. GingRAs. 1997a. Sequence stratigraphy and sedimentary facies of the Lower and Middle Triassic of northeastern British Columbia: progradational shoreface associations in a mixed carbonate siliciclastic system. Field Trip Guide, Sedimentary Events-Hydrocarbon Systems, 1997. Canadian Society of Petroleum Geologists - Society for Sedimentary Geology joint convention, Calgary, $188 \mathrm{p}$.

ZonNeveld, J.-P., T. F. Moslow, AND C. M. HeNDERSON. 1997b. Lithofacies associations and depositional environments in a mixed siliciclastic-carbonate depositional system, upper Liard Formation, Triassic northeastern British Columbia. Bulletin of Canadian Petroleum Geology, 45(4):553-575.

ACCEPTED 10 MAY 2003

APPENDIX I

Characters used in the phylogenetic analysis

1. Carapace cross-section. 0, laterally compressed; 1, dorsoventrally compressed; 2, subcylindrical; 3, flat.

2. Median suture. 0 , suture absent; 1 , suture present

3. Fusiform intercalated plate. 0 , absent; 1 , present.

4. Cephalic ridges. 0, weak to absent; 1 , present.

5. Attachment site of the adductor testis muscle. 0, absent; 1 , defined by ventral bifurcation of branchiocardiac groove; 2 , defined by ventral extensions of postcervical and branchiocardiac grooves.

6. Urogastric groove. 0 , absent; 1 , present.

7. Cervical groove. 0 , does not cross midline; 1 , crosses midline; 2 , absent.

8. Branchiocardiac groove origin. 0 , weak to absent; 1 , arises at hepatic region; 2 , arises at height of gastro-orbital groove; 3 , arises at postcervical groove.

9. Postcervical groove origin. 0, absent; 1, arises at height of gastroorbital groove; 2 , arises at branchiocardiac groove; 3 , arises at hepatic groove.

10. Intercervical groove. 0 , absent; 1 , present.

11. Hepatic groove. 0 , absent; 1 , present.

12. Inferior groove. 0 , weak to absent; 1 , present.

13. Chela type. 0 , chelate; 1 , subchelate; 2 , achelate.

14. Chela number. 0 , chelae on first through third pereiopods; 1 , chelae on first and second pereiopods; 2 , chelae present only on first pereiopod; 3 , chelae on first through fourth pereiopods; 4 , no chelae.

15. First pereiopod. 0, first through fifth pereiopods nearly equal in size; 1 , first pereiopod longer or more robust than second through fifth; 2 , first pereiopod much longer than second through fifth; 3 , third pereiopod longest.

16. Dorsal ridge on abdomen. 0 , absent; 1 , present.

17. Abdomen shape. 0, sharp bend in abdomen; 1 , abdomen nearly straight; 2, abdomen asymmetrical; 3, abdomen folded under carapace.

18. Telson. 0 , no transverse ridge or suture on telson; 1 , transverse ridge present; 2, transverse suture present; 3 , posterior portion of telson not calcified.

19. Diaresis of exopod of uropod. 0 , absent; 1 , present; 2 , uropods absent.

20. Lineae. 0 , absent; 1 , present.

21. Fractosternum. 0, absent; 1, present. 
APPENDIX II

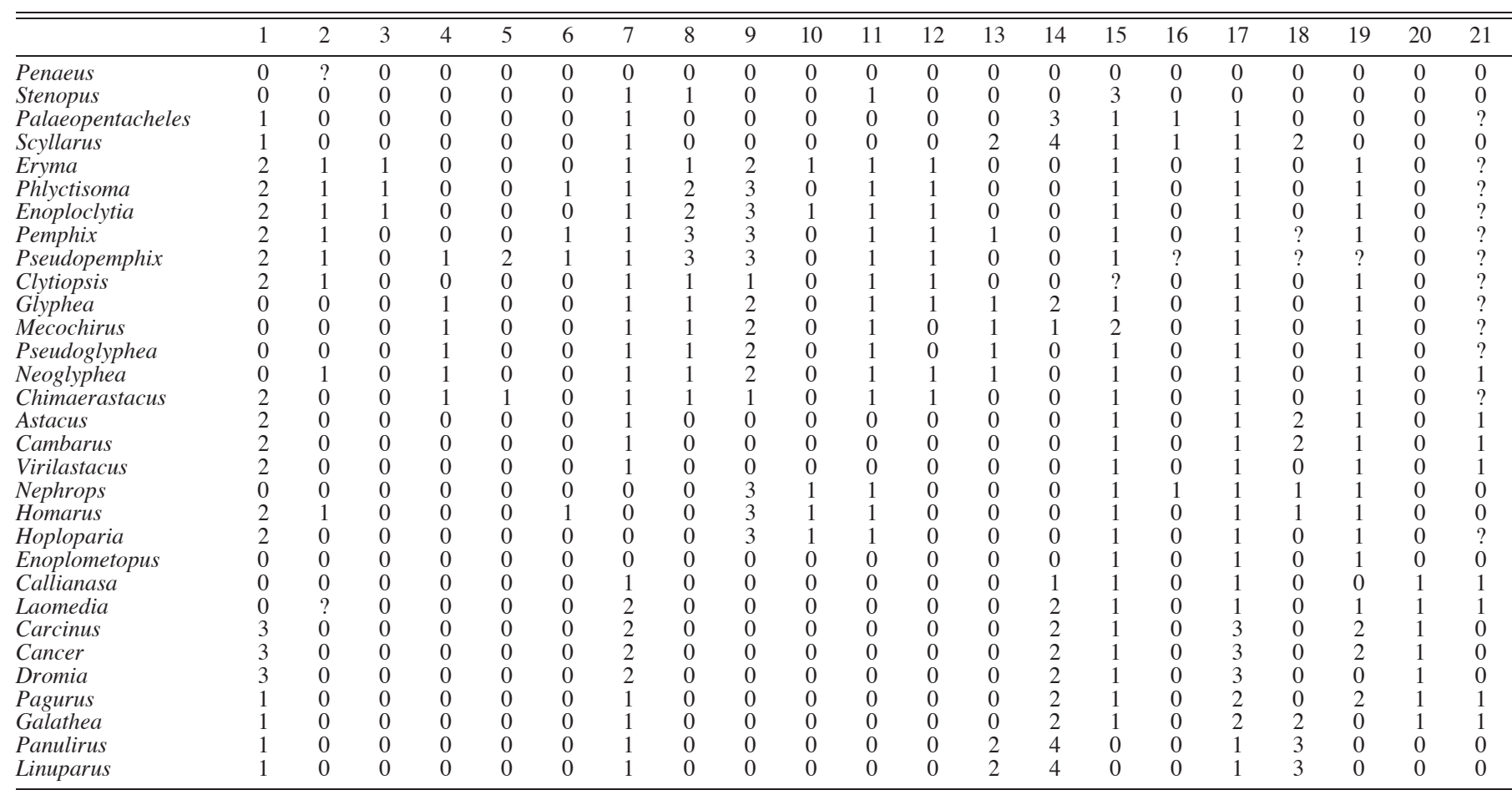

